MANAGING CRISIS AND LIVING IN CRISIS: HEALTH \& PLACE, WHAT SEPARATION? A HOLISTIC VIEW OF THE COMMUNITY ENVIRONMENT AT SHERBOURNE AND DUNDAS

By

Stephanie Beausoleil BSW, York University, 2012

\author{
An MRP \\ presented to Ryerson University \\ in partial fulfillment of the \\ requirements for the degree of \\ Master of Social Work \\ in the Program of \\ Social Work
}

Toronto, Ontario, Canada, 2019

C) Stephanie Beausoleil 2019 


\section{AUTHOR'S DECLARATION FOR ELECTRONIC SUBMISSION OF A MRP}

I hereby declare that I am the sole author of this MRP. This is a true copy of the MRP, including any required final revisions.

I authorize Ryerson University to lend this MRP to other institutions or individuals for the purpose of scholarly research.

I further authorize Ryerson University to reproduce this MRP by photocopying or by other means, in total or in part, at the request of other institutions or individuals for the purpose of scholarly research.

I understand that my MRP may be made electronically available to the public. 


\begin{abstract}
MANAGING CRISIS AND LIVING IN CRISIS: HEALTH \& PLACE, WHAT SEPARATION? A HOLISTIC VIEW OF THE COMMUNITY ENVIRONMENT AT SHERBOURNE AND DUNDAS

Master of Social Work, 2019

Stephanie Beausoleil

Program of Social Work, Ryerson University
\end{abstract}

A person's environment greatly influences and informs their emotional health, wellbeing and ability to live with dignity and express agency. The Sherbourne and Dundas neighborhood presents a matrix of spaces entrenched with high levels of violence, incivilities and public health hazards. Currently, there are numerous institutions working within and surrounding this community all with a mandate to support the vulnerable and stigmatized who live here yet to date has not been actualized on any level at Sherbourne and Dundas. The environmental living conditions for the neighborhood and the participants of this study are quickly deteriorating putting everyone within and surrounding the area at increased risk. Findings of this narrative study with three residents indicate that there to be a stronger balance between community and service user voice in developing and informing programming as well at determining who occupies space in their environment as 'helpers 'and other structural and systemic representations which yield a great amount of power as brokers in this marginalized and vulnerable neighbourhood space. In doing so this community would be able to hold power accountable in this environment, disrupt the hybridization of institutionalization that is in effect in this space. 


\section{ACKNOWLEDGEMENTS}

A great many thanks go to all of my many teachers, mentors, helpers, and other multidimensional, multi-form inspirations.

A thousand thank you's to all the courageous and determined people who gave me trust and welcomed me into their homes, hearts and stories to carry these testimonies forward unlocking the gates so that we may reclaim the community environment for our own agency, welfare and step into being truly responsible to one another as the very inheritors and stewards of this land and space.

Finally I would like to acknowledge my Beloved who has inspired me to keep learning and has helped build the fire in my heart. May the gods make it so that your home and your horn be fruitful in the time to come. Skål! 


\section{DEDICATION}

To all those who live there, lived there, died there.

To those who try and have tried to make it better.

To all those who have given years, tears, countless cigarettes, opened their doors and hearts, even after being burned, beset by grief and disappointed.

To all those who have given, even in 'small ways', because even a little light against the night sky inspires so much.

To all those who have been judged, hated, service restricted, aged out and left outside to suffer together.

To all those that continue to support one another, in the midst of a battle you did not create in this violent war that quietly blames and mines the maimed.

To those who continue to do this role of helping your neighbour, knowing that it is truly is heartbreaking, consuming, and humbling humanitarian work.

To all of you I give my greatest thanks and say soar like eagles together above the deluge and continue growing your mind and heart! We are not in this alone.

Shields, hearts and swords up! 


\section{TABLE OF CONTENTS}

CHAPTER 1. INTRODUCTION

Background \& Context $\quad 4$

$\begin{array}{lr}\text { Theoretical Lenses } & 8\end{array}$

Positionality in Relation to the Study \& Social Work $\quad 11$

$\begin{array}{ll}\text { Research Objectives } & 14\end{array}$

CHAPTER 2: LITERATURE REVIEW 16

Place Identity \& Social Capital 17

$\begin{array}{ll}\text { Spatial Justice } & 22\end{array}$

$\begin{array}{ll}\text { Social Cohesion } & 24\end{array}$

$\begin{array}{ll}\text { Health \& Connections to Place } & 25\end{array}$

Gaps in the Literature \& Research Questions 27

CHAPTER 3: RESEARCH METHODOLOGY-STORYING \& RE-STORYING 33

Recruitment \& Participants $\quad 34$

$\begin{array}{ll}\text { Data Collection } & 35\end{array}$

$\begin{array}{ll}\text { Data Analysis } & 37\end{array}$

$\begin{array}{ll}\text { Research Limitations } & 38\end{array}$

CHAPTER 4: FINDINGS- THREE STORIES OF THE NEIGHBOURHOOD 40

$\begin{array}{ll}\text { Temporality } & 42\end{array}$ 
Place

Sociality

CHAPTER 5: DISCUSSION \& IMPLICATIONS - NEW BEGINNINGS 


\section{LIST OF APPENDICES}

Appendix A - Recruitment Flyer

Page 74

Appendix B - Consent Form

Page 76

Appendix C - Interview Guide

Page 80

Appendix D - Resources for Participants

Page 82

Appendix E - Ethics Approval Certificate

Page 83 


\section{CHAPTER 1. INTRODUCTION}

"First say to yourself what you would be; and then do what you have to do." Epictetus

The purpose of this narrative inquiry (NI) conducted with three community members was to explore local knowledge through volunteered testimony and document some of the impacts that the community environment (social, structural and built) at Sherbourne and Dundas has had and is having on the residents. Through this intentional dialogue, community members disclosed a type of specialized urban environmental knowledge about their community. They reveal the multiple layers, constructions, representations, challenges and changes they have experienced, been impacted by, resisted and survived through. These dialogues and the following discussion help to unmap certain stigmas and reveal portents of power, all of which offer the reader a signal about the future of this highly dense and vulnerable community and the city writ large.

The participants' insights and unique lens into their environments also helped to foster a pooling of shared themes, perceptions and concerns which bring to light the multifaceted impacts that this particular environment's dynamic has on the health, wellbeing and futurity of the people who live here. Admittedly, this inquiry was done within a short window with three participants from the community. This researcher offers this study as a token towards encouraging much larger, more collaborative and scaled-up opportunities for further explorations into the impacts that this particular community has had/is having on the wellbeing, health, safety and stability of its members, especially those who are marginalized and vulnerable. For those who work in social services, are community stakeholders and those who work on behalf of the state, this NI gives a 
direct voice of those people who live with the policies, structures, actions and decisions made or chosen not to be made by stakeholders.

Currently, there are numerous institutions working within the community that seek to alleviate and provide programming and housing in response to the immense suffering present here. However, they have largely failed. The intention to help is there, but one needs only look at corner of Sherbourne and Dundas with open eyes, not even look closely, just observe and the failures of these institutions are self-evident. This paper presupposes that those who are receiving supports and living within the environment of Sherbourne and Dundas, the ones who need the help are also the ones who know best how they are affected (or afflicted by the environment and the many actors and structures embedded within it). This counters the current paradigm which presupposes that the policy makers, agencies and their workers know how best to support this community.

By conducting one-on-one interviews with individuals impacted and influenced by the structure of this environment occupied by these institutions this paper illuminates the lived experience of some of our societies most disenfranchised, stigmatized and distraught peoples. The interviews helped to unmap some of the geography of this space through individuals' stories which reflect their lived(ing) experiences and their situated stories over time in place. I explored through this intimately in-depth offering the community members' shared through their dialogues, expressing their concerns, challenges, acts of resistance; as well as visions of the future for this urban neighborhood. It is because of the courage and openness of those who participated that their knowledge acts as counter stories to the dominant narratives and disrupts the silencing that this community has experienced presenting an opportunity for greater context, 
self-reflection, and enabling greater community cohesion by building this neighborhood's testimony and shared meaning (Isaacs, 1993).

The purpose of this paper is to amplify and recentre the epistemological awareness held by community members through presenting the social facts existing within their living environment and then brings it into the public and political sphere. Furthermore, this inquiry intensifies conversations about why it is important to challenge the current perceptions held regarding the significance and consequences that environments of social-political disorder has on individual and collective wellbeing and what it means in terms of upholding spatial justice (Eagle, 2015). The reflective discussions are articulated through a synthesis of lenses from community and environmental psychology, which hold within them understandings of spatial justice and critical architecture in relation to the community environment and unmapping power representations within them (Eagle, 2015; Williams-Goldhagen, 2017). These concepts help to reveal how the ambient and physical environment within is intimately connected with cognition, body and space and its futurity. It is through these discourses that I will link the ways in which this marginalized community is shaped and influenced by both the built and social environment experience. I also review the ways in which this particular environment acutely influences the agency, recovery and outcomes of the most vulnerable people who live in as well as access services within these spaces. Through their testimonies, I will share how living in this atmosphere has informed their identity and their ability to navigate their inner and outer worlds, reflecting the many complicated and dynamic relationships forged in resistance to confront the flood of challenges which are historical, complex, and entrenched. 
This research inquiry will lead to further community-based and inter-sectoral research which could inform targeted policy changes that are both peer-informed as well as interprofessionally approached.

\section{Background \& Context}

Sherbourne and Dundas holds a unique position in the city of Toronto as it is part of set of historic communities belonging to the Garden District. It is also surrounded by other established historic neighbourhoods: Cabbagetown to the east, Rosedale, St. Jamestown and The Village to the north, Moss Park to the south; and Toronto's major urban centre Dundas and Yonge just minutes away to the west; this has always been a lively space with many stopping and passing through it. Along with being an established community it is a historically marginalized an incredibly dense stigmatized community which has strikingly high crime rates, violence and socioeconomic deficits (Bailão \& Wong-Tam 2019; Brillinger, 2018; Hande, 2018).

This geographical area has many deeply entrenched issues which require immediate and long-term responses in order to disrupt the levels of violence and instability which has put this neighborhood under occupation. The opening of emergency response sites to housing and health crises coupled with rapid revitalization and densification surrounding this area only further complicates them myriad of growing challenges faced by this vulnerable and marginalized community. The main issues that Toronto's City Council has acknowledged as long-standing (Bailão \& Wong-Tam 2019; Brillinger, 2018); includes high proportions of people with mental health concerns, high overdose rates, high rates of substance use, high prevalence of poverty, lack of affordable and accessible housing and supportive housing options. Although the neighborhood has historically had issues with violence and crime (Doolittle, 2009), over the past several years there have been large spikes in violent incidents (Bailão \& Wong-Tam 2019; 
Brillinger, 2018). Between 2016-2017 there was a 53\% increase in critical incidents of violence within the community and the surrounding areas within the downtown east (Brillinger, 2018). It is important to note that these metrics concerning Dan Harrison and Sherbourne and Dundas neighborhood (Toronto Community Housing, 2018), arrived after already receiving the title and stigma of having the highest rate of violence per capita in the nation (Doolittle, 2009).

The Dan Harrison Community Complex is just one of the social housing buildings in the Sherbourne and Dundas area and has been cited by the City of Toronto as being an important asset of the Toronto Community Housing Corporation (Bailão \& Wong-Tam 2019) as it is the very first site of Toronto's social housing. This resulted after Jane Jacobs and a group of activists and residents came together in 1973 to save the houses from being demolished during urban renewal and as a result of their success the city of Toronto bought the site for social housing starting the non- profit City Homes (Bozikovic, McHugh \& Pahwa, 2017).

Dan Harrison Community Complex on its own has housing for 428 residents. It has 17 rooming houses and two low-rise apartment buildings composed of 376 units which primarily host bachelor units, but also has one to four bedroom units contained within (Bailão \& WongTam 2019). There are singles, couple, families, elderly and youth reside at this location, which is important to consider in the context of this environment and its impacts on the residents, which are many, when reading through the rest of this paper.

Many of the residents living at Sherbourne and Dundas are exceptionally vulnerable for a number of reasons as most of them disproportionately experience poverty, violence, crime, and inadequate and unhealthy housing conditions (Bailão \& Wong-Tam 2019, Toronto Community Housing, 2018). The community has not been silent about the state of neighborhood environment either as complaints of the crisis in living conditions being documented and reported going back 
almost thirty years (Bailão \& Wong-Tam 2019). Many of the residents who live at Dan Harrison and in the neighboring houses live with various medical and/or substance uses challenge, and/or mental health issues, (Bailão \& Wong-Tam 2019; Toronto Community Housing, 2018), some have been institutionalized and have challenges related to re-integration (Toronto Community Housing, 2018), and/or are in transition from violent and traumatic situations and are here trying to recover. These vulnerabilities and complexities are further compounded by the broader failure of a series of on and off-site actors, agencies and other power structures to address chronic and systemic issues and service/ support gaps including provision of effective on-site wrap-around services, access to treatment and detox supports and much needed mental health supports (Bailão \& Wong-Tam 2019), which are patient centred, trauma informed and culturally relevant.

The structural issues facing this community were identified and listed in a motion drafted by Councillor Kristyn Wong Tam and Councillor Ana Bailão (2019), as being as part of a broader historical lack of continuity and commitment towards addressing the issues at the Dan Harrison Community Complex and its surrounding neighborhood of Sherbourne and Dundas. Bailão and Wong Tam (2019) also cited the lack of safety and security within Toronto Community Housing (TCH), social housing residences, and in the community; as well as concerns with the lack of communication within Toronto Community Housing's management structures and in their communications with the residents living in social housing within the neighbourhood (Bailão \& Wong-Tam 2019).

The issues raised by Bailão \& Wong-Tam (2019) about the social housing environment in the Sherbourne and Dundas neighbourhood were backed up in another report drafted to the Tenant Services Committee from the Senior Director of the Community Safety Unit (Toronto Community Housing, 2018) which stated that "since 2015, the Dan Harrison community has 
seen significant year-over- year increases in the frequency and severity of anti-social activity which includes violent crimes and non-violent crimes"(Toronto Community Housing, 2018). The crime trends at Dan Harrison emphasize the rise in "discharge of firearm (danger Life)"(Toronto Community Housing, 2018) going from 19 incidents in 2015 and doubling to 38 by 2017 (Toronto Community Housing, 2018). Within the same report, the Senior Director of the Community Safety Unit highlighted that the Dan Harrison Community Complex and the two other buildings within the Sherbourne and Dundas neighborhood, Pembroke Mews and William Dennison Apartments (a seniors' building), had a significant increase of over $300 \%$ in incidents of anti-social behaviour in the same three year period going from 315 anti-social acts in 2015 to 1, 168 reported anti-social incidents (Toronto Community Housing, 2018). TCH (2018) admitted that these specific crime trends have continued to grow "despite the deployment of significant security resources, the current utilization of third party security services" and that even with these changes to enhance the security of the community environment that it "has been ineffective in improving the feeling of safety for the tenants in these TCHC communities" at Sherbourne and Dundas (Toronto Community Housing, 2018).

$\mathrm{TCH}$ then committed to spending nearly a million dollars in 2018 to initiate a new 12month pilot of community -based safety model and implement an intelligence-based enforcement in order to "expedite dispute resolution and prevent minor disputes from escalating into violence (Toronto Community Housing, 2018). In the motion drafted by Bailão and Wong Tam (2019), it was additionally stated that the community agencies and partners holding space and operating within the Sherbourne and Dundas neighbourhood also had 'structural challenges' using descriptors of their performance such as 'burned out', 'lacking adequate capacity', 'understaffed', 'overworked' and that they were 'working in silos'. Furthermore Councillors 
(Bailão \& Wong-Tam 2019), noted the systemic issues in this environment impacting and influencing the residents' wellbeing as including lack of safety and security, drug trafficking, unsafe sex-work, crime, violence, social service and delivery gaps, and a history of inaction and feeling of neglect/ not being heard (Bailão \& Wong-Tam 2019) all which increased the already marginalized community residents' levels of vulnerability and persistent elevated risk.

This is all important to consider given that this urban community also functions as a critical vein entering the downtown core, and is also a neighborhood hosting numerous families, elderly, people in transition from institutions, people using substances, people with serious health conditions, mental health conditions, mobility issues, acquired brain injuries, other cognitive issues, as well as those trying to move into reducing and/or recovery (Bailão \& Wong-Tam 2019; Toronto Community Housing, 2018). In parallel with the population of this small neighborhood, there are many emergency and social service agencies for Toronto including shelters, respite services, drop-ins, social housing units, young-mothers' home (The Robertson House), social service agencies and health centres, as well as a safe injection site, all within a three-block radius; all this, lending great complexity to understanding this neighbourhood.

\section{Theoretical Lenses}

\section{Structural Functionalism}

Keeping the complexity of the neighbourhood as well as the issues affecting residents in mind, this MRP relies on several theoretical lenses discussed in detail here. One such important lens is structural functionalism which emerges from the discipline of sociology and social sciences and Herbert Spencer and Robert Merton were the main founders and contributors to this theory (Moffitt, n.d.). It is a framework for building theories which see society as a complex matrix of systems, whose parts, ideally, work together to promote social cohesion, inclusivity 
and stability (Moffitt, n.d.). The key tenets of structural functionalism are social structure, manifest functions, social functions and latent functions (Moffitt, n.d.). It asserts that our lives are guided and influenced by social structures, which are largely shared and promote relatively stable patterns of social behaviour. These structures are representations within our environments influence, shape and inform our lives such as in the family, community and other aspects which all contribute to our individual and collective health and wellbeing (Moffitt, n.d.). Through this paper, I will be seeking to unpack the social and structural environment through this lens to help me better understand how the matrix of structures, actors and systems within this community directly and indirectly impact the lives of those who live at Sherbourne and Dundas.

\section{Enviro psychology}

Environmental psychology is the ecology of behaviour (Gee \& Spencer, 2009), meaning that it appreciates the environment as being intimately intertwined with self, reasoning, cognition, identity and so the environment becomes a major influencer on the individual and the collective, such as informing and forming community's health and wellbeing and vice-versa (Eagle, 2015; Williams-Goldhagen, 2017). This theoretical lens relates to structural functionalism in that it takes a systemic view of the interconnectedness of structures and the social, natural and man-made space and pushes further into a more holistic and reciprocal view bridging the human with the environment (Capra. 1996; Williams-Goldhagen, 2017). In using this lens, I was able to delve deeper and look not only intersectionally but also interdimensionally at the way in which the many representations in this neighbourhood's environment shapes, influences and directs not only the way community members move through the environment but show how also how work to unmap how the environment moves through 
and even stays with them (Eagle, 2015; Williams-Goldhagen, 2017), in the way of emotions, triggers, memory and influencing decision making and expression of agency.

Enviro psychology re-centres humans as one with space, our bodies and minds constantly engage in reciprocal communication with our social, structural built and natural environments whether we are cognisant of it or not (Capra, 1996; Eagle, 2015; Shepard, 1982; WilliamsGoldhagen, 2017). This lens helps to push the discussion and importance of community and spatial justice beyond limited reality of identity politics and strictly human constructs to make room for conversations about how space is influencing and is simultaneously being influenced by peoples' emotions, physical health and mental health. Environmental psychology takes up theories which consider place, place attachment, and place identity; and consider how stress related to physical settings inform the psychosocial environment in space. This theory considers the social use of space, including the impacts of crowding, levels of privacy, issues related to territoriality; and the access to personal space. Environmental psychology also looks critically at the social, structural and political aspects which underpin resource management, such as placement and accessibility of safe spaces. Furthermore, it considers the level of services within a community and considers data including metrics or other reporting data on local-level crises including those that inform and pose health and environmental risks and hazards. These include changes in perceptions of safety, changes in social order, including those related to management thereof; and the impacts this has on the individual and community's wellbeing. All of these are looked at wholly and will help me to better understand the ways in which these occurrences compound one another and act as presages in the environment of Sherbourne and Dundas.

\section{Community Psychology}


Community Psychology is the branch of psychology involved with person- environment interactions and the ways in which society affects both individual and community functioning (Nation \&Wandersman , 1998). This approach meshes perfectly with the positions and discourses found within enviro psychology and structural functionalism. Community psychology uses a systems approach to unmap the social issues, social conditions, social institutions, and other settings that influence individuals, groups, and organizations (Bond, 2004; Eagle, 2015; Nation \&Wandersman,1998). This unmaps and studies human engagement and interactions in their multiple historical cultural, ecological, and sociopolitical contexts (Eagle, 2015; Harrell, 2014), and its core values underpin its frameworks. These include pursuing social justice for all individuals in a community by working with them unpack the power structures and empower those who are marginalized to navigate them and even inform them at the individual and community level (Dalton et al., 2015; Eagle, 2015; Harrell, 2014). This collective effort aims to enhance the quality of life through collaborative research and action (Dalton et al., 2015). Much of the research within this framework is conducted to develop a better understanding of how individuals' behavior, agency and relationships are influenced by the environment, social and community aspects (Eagle, 2015; Nation \&Wandersman, 1998; Roundtree, 2011). Through this theoretical lens, I will gather individuals' representations and experiential stories of living within this neighborhood environment and how they see it influencing and connecting to their own self-determination and their community's future.

\section{Positionality in Relation to the Study \& Social Work}

I have had over a decade of experience doing work concerning mental health and addictions, community capacity building and researching state policy. I have worked independently and collaboratively undertaking consultancy work on more than several projects, 
including reviewing and drafting measures for accountability, performing national and international research on best practices, on better supporting marginalized groups and communities. Additionally, I have extensive experience in community organizing wherein I worked within local groups to identify, nurture and develop leadership skills for individuals and help create opportunities for collective efficacy and public consciousness raising within the nonprofit sector. It is from the above experiences that I understand the importance of a wellinformed, trained, supported and involved team and community. More recently I have engaged in frontline work in the downtown east providing community supports and crisis intervention where needed while also attending Ryerson University which sits on the periphery of this neighbourhood. Both living and working in this community I have heard, seen and experienced what happens at the end of the work day in this space and know firsthand some of the emotional and heightened states that this sporadically volatile environment can yield and trigger.

In the time I have been at Sherbourne and Dundas I have witnessed and participated in the growing non-linear dynamic between community members, agencies and various stakeholders and the themes that flow out and between them, some dialogues leading to greater shared meaning and others deepening the lien that divides. The situation in this neighbourhood has morphed dramatically as well as the positions and perspectives on the myriad of complex situations. Over the past year there have been many safety walks, tables, meetings, letters and side street conversations with residents and stakeholders alike all coming together to specifically focus on issues impacting the community members, the businesses and the agencies within their neighborhood environment. I have taken the much-needed space to reflect on what it means to the community and what it means to me as someone who was invited into this space to live, 
sleep and do work and how much it impacted me after meeting the many people who live here and try to heal here.

The experiences in and with this community both the people and the environment have inspired me to go back to school and do my Masters and get these living stories of space out there into the public view. Through reflecting it was clear to me that I could use the opportunity of this research paper to leverage a space within the institutions surrounding and impacting the people here, to bring community members' specialized environmental knowledge of their community to the table. This was an opportunity to centre their knowledge and to amplify their experiences so that it would be represented in their own words, potentially acting as a counter narrative to the funding applications which often are the only spaces where some representation of the state of crisis gets related. Funding applications and reports to stakeholders sadly are often the only place where some representation of the people living in and accessing services within Sherbourne and Dundas get told and they are often told/penned by people who for the most part get to leave this neighborhood and its reality at the end of their work day. Yet this is not something new, this is still the same unchecked power which gets to articulate the function and purpose of this neighborhood space in the decades before and for the ones to come. Being that this is the status quo I wanted to help challenge the entrenched perceptions and prescriptions and deepen awareness through resident and service users' stories in order to bring more clarity and a greater context to the entwined realities of this community and what it is like to experience and be impacted by this space. My offering through this NI is to help in weaving just some of these voices into the narrative, stories that we all need to hear, the living experiences of community members managing crisis and living in crisis in the Sherbourne and Dundas neighbourhood. 


\section{Research Objectives}

The purpose of research in this tradition is to unearth not only sociocultural knowledge about this specific built and social environment of this neighborhood with a focus on how violence and power operates in direct and hybrid pathways in this historically marginalized community. The research lens from the structural functionalist paradigm is useful for uncovering patterns of spatial and social injustice because it is the power of the built environment in which "places situate us as individuals amongst others" (Williams-Goldhagen, 2017, p. 181). It also informs us in many ways to what we think we are capable of; "feeding into the narrative streams of our lives" (p. 208). This research through NI needs to be done not for the purposes of pathologizing or problematizing this already stigmatized community, but needs to take place in order as part of an initial response to concerns which community members have repeatedly identified as impacting their ability to connect and interact with the people and environment around them. This study is just one step in the beginning of a much long-journey to support the many people who make this place their home.

Through one-on-one interviews with community members, this research helps to unearth and unmap some of the geography of this space through individual stories which reflect their lived(ing) experiences, situated stories over time in place. Anchoring community members' knowledge within these conflicted spaces through narrative inquiry transcends the need to have consensus- based, (Isaacs, 1993), often top-down epistemologies and shatters the comfort zones of thought which work to suffocate our understandings of the diversity of interpretations about the complexity of places we live and the impact that it has on us (Eagle, 2015; WilliamsGoldhagen, 2017). This is an intentional strategy to engage neighbourhood residents in creating a pool of shared meaning to build agency and community self-determination. This research will 
also be an accessible document of testimony which may inspire further research and lead to new levels of coordinated action.

Within the academic community this contribution can bolster a broader multi-disciplined re-contextualization of health and place and through the NI push conversations and actions which challenge traditional approaches to practicing and occupying space in vulnerable communities. This inquiry also seeks to expand upon the current perceptions concerning the significance and reciprocal impacts confluent in the environments we live, individual cognition and how it influences our collective wellbeing. It is hoped that the findings will stimulate scholarship, inspiring new ideas and action, within the community, social work institutions and the profession. This research also aims to contribute in a small part to the conversation about the city's planning and policies in relation to community, health, wellbeing and the need to preserve and build upon foundations which strengthen social cohesion and belonging (Bassett \& Moore, 2013; Eagle, 2015; Berado, et. al., 2018; Hande, 2018; Lopez, 2009; Norma, Chiara, \& Katiuscia, 2013; Nation \&Wandersman, 1998). 


\section{CHAPTER 2: LITERATURE REVIEW}

The literature review presented in this chapter will help ground the reader in the research, findings, and theories as well as provide some clarity on the use of the terms that I put forth in the paper which have helped to inspire the framework for designing this place-based NI. There have been growing discussions over the past few decades within and across the disciplines of community and environmental psychology, health and place, and critical urban design which looked extensively at the ways in which the built and ambient environment influences sensory perception, community safety, recovery, health and wellbeing (Bassett \& Moore, 2013; Bond et al., 2012; Eagle, 2015; Corsínjiménez, 2003; Berado et al., 2018; Aubry et al., 2011; Lopez, 2009; Brown et al., 2005; Mitchell \& Popham, 2008; Saccone, 2011; Williams-Goldhagen, 2017).

The currents of these discussions hold concepts which align with the social work principles of anti-oppression, social justice and spatial justice (Eagle, 2015; Corsínjiménez, 2003; Berado et al., 2018; Aubry et al., 2011 Mitchell \& Popham, 2008; Saccone, 2011; Williams-Goldhagen, 2017). The literature engaged with critical theoretical perspectives in unmapping social and systemic powers in order to bring coherency to promoting community capacity, health and enhanced safety and stability of space (Eagle, 2015; Hande, 2018; Mitchell \& Popham, 2008; Saccone, 2011). These concepts consider the vulnerability of those who are marginalized within these complex environments and the ways in which various actors, systems and infrastructures, or lack thereof (Eagle, 2015; Hande, 2018), influence healing, recovery and wellbeing within the community, environment, and the self. These frameworks and theories helped contextualize the multi-layered, intersecting realities that both shape the people and are shaped by the people in neighborhood environments (Bassett \& Moore, 2013; Berado et al., 2018; Bond et al., 2012; Capra, 1996; Corsínjiménez, 2003; 
Eagle, 2015; Aubry et al., 2011; Lopez, 2009; Brown et al., 2005; Mitchell \& Popham, 2008; Saccone, 2011; Williams-Goldhagen, 2017).

\section{Place Identity \& Social Capital}

For well over sixty years, urbanization and the impacts it has on psycho-social wellbeing have been studied (Bassett \& Moore, 2013; Berado et al., 2018; Dunn, 2002; Evans et al., 2008; Nation \& Wandersman, 1998). Many great observations and theories were developed to speak critically with regards to the psychosocial effects that urban environments, with emphasis on subjects who are socio-economically disadvantaged, have on the people who live there (Bassett \& Moore, 2013; Dunn, 2002; Evans et al., 2008; Nation \&Wandersman, 1998).

The environment we live in both the physical and ambient (sights, smells and sounds) has considerable impact on our physical health our sense of identity (Eagle, 2015; Shepard, 1982; Williams-Goldhagen, 2017). How we connect with our neighbors, the kind of networks we are able to establish; and what levels of social capital we possess are all indicators which influence of our social determinants of health (Bassett \& Moore, 2013; Berado, et. al., 2018; Dunn, 2002; Nation\& Wandersman, 1998). Life satisfaction and quality of life are important measures and aspects to both individual and public health and key determinants for actualizing agency. Therefore, they should not be discounted by policy makers and those concerned with public health and crisis management, especially in cities that are rapidly amplifying densification of their citizenry (Bassett \& Moore, 2013; Berado et al., 2018; Dunn, 2002; Rogers et al., 2008; Nation \&Wandersman, 1998). 


\section{Community Safety \& Its Relationship to Mental Health \& Wellbeing}

Urbanization, densification, and the psychosocial impacts it has on place identity as well as the implications it has on health and wellbeing have been researched and discussed through the lenses of architectural philosophy, health literature, community psychology and enviro psychology (Bassett \& Moore, 2013; Berado et al., 2018; Bissonnette et al., 2012; Dunn, 2002; Eagle, 2015; Hande, 2018; Rogers et al., 2008; Nation \&Wandersman, 1998; WilliamsGoldhagen, 2017).

Early contributors to the field of community psychology drew clear definitions and demarcations in what they understood as safe and stable communities (Lewin, 1936; Shepard, 1982; Nation \&Wandersman, 1998). Researchers also had no issue with naming and discussing what they saw as rampant and sprawling social disorder and incivilities, especially in socioeconomically depressed communities (Rogers et al., 2008; Nation \&Wandersman, 1998). They took strong positions in emphasizing the importance of safe, stable and inclusive environments and the need for a culture of order within community spaces (Eagle, 2018; Hughey, Perkins \& Speer, 2009; Nation \&Wandersman, 1998). Research regarding neighbourhood environments has continued to focus on and emphasize the correlating psychosocial impacts of the environment on individual health and the importance of building and securing spatial justice for greater social cohesion and wellbeing (Eagle, 2015). Within these discourses there is a recurring theme which speaks to people's perception of their environment, including perceptions of safety (Bissonnette et al., 2012; Eagle, 2015; Hande, 2018; Mitchell \& Popham, 2008; Nation \&Wandersman, 1998). Much of the literature I found focused on marginalized groups experiencing intersecting socioeconomic and structural inequities. Researchers (Kondrat, 2013; Lopez, 2009; Rogers et al., 2008) looked for causation and correlations between the community environment, 
neighbourhood identity and health outcomes and how it might be perpetuated by the social and built environments.

Another common theme within the literature is the correlation between mental health, wellbeing and its relationship with public health and safety (Bissonnette et al., 2012; Lopez, 2009; Nation \& Wandersman, 1998). Ellaway et al. (2014), Berado et al. (2018) and Bissonnette et al. (2012) found mutually reinforcing relationships between the psychosocial and environmental aspects of neighborhoods. These relationships were more pronounced in marginalized communities where there was greater socioeconomic disparity, housing insecurity and more pronounced health issues (Bassett \& Moore, 2013; Berado, et. al., 2018; Berg et al., 2010; Bissonnette et al., 2012; Hande, 2018; Kondrat, 2013; Nation \&Wandersman, 1998).

A number of scholars looked specifically at the impact that neighborhood incivilities had on compounding mental health and the ways in which these environments placed vulnerable people at higher- risk in communities already overwhelmed with socioeconomic marginalization and oppression (Bassett \& Moore, 2013; Bissonnette et al., 2012; Eagle, 2015; Hande, 2018). Research indicates that individuals within these urban neighborhood environments which already presented a "deprivation in the living environment- including air pollution" (Mitchell \& Popham, 2008), higher rates of crime, and lowered perceptions of safety (Nation \&Wandersman, 1998).

Current research and discourse also show strong associations between metal health and the physical and built environment (Bond et al., 2012, Eagle, 2015, Hande, 2018; Shepard, 1982; Williams Goldhagen, 2017). The research consistently demonstrates that residents who live in deprived areas consistently present poorer mental health and physical health than those who live in less deprived areas, showing a correlation between the environment and wellbeing (Aubry, 2011; Berado, 2018; Bissonnette et al., 2012; Bond et al., 2012, Dunn, 2002; Eagle, 2015, 
Hande, 2018; Shepard, 1982; Williams Goldhagen 2017). The majority of literature I found in my review supported the theory that there are clear reciprocal psychosocial impacts that the environment has on individual agency and collective wellbeing (Eagle, 2015; Hande, 2018; Mitchell \& Popham, 2008). Research with this focus has largely emphasized the importance of people's perception of their environment, perceptions of safety and its relationship to fear of crime (Eagle, 2015; Mitchell \& Popham, 2008; Shepard, 1982; Wandersman \& Nation, 1998; Williams-Goldhagen 2017). This research was situated within an ecosystems framework, and looked for relational and holistic views of place and space ( Eagle, 2015; Williams- Goldhagen, 2017).

Furthermore, the literature emphasized the mutually reinforcing, compounding effects that relationships between the psychosocial and environmental aspects of neighborhoods' had in impacting multiple dimensions of social determinants of health, which deficits were more pronounced in marginalized communities impacted by socioeconomic disparity, housing insecurity, higher incidents of violence, crime, fear of crime (Eagle, 2015; Wandersman \& Nation, 1998), constant states of trauma (Eagle, 2015; Hande, 2018; Mitchell \& Popham, 2008) and more pronounced health issues (Bassett \& Moore, 2013). Mitchell and Popham (2008) compared income-related health inequality in areas with different levels of accessible greenspace; and found strong associations between the physical environment and its impacts on mental illness and levels of mortality. Bassett and Moore (2013) took a similar stance in their research questions but expanded it to better appreciate the psychological impacts that neighborhood incivilities had in compounding negative outcomes on the health and wellbeing of residents within marginalized neighborhoods. 
The majority of research I found was interested in seeking data from populations which were already overwhelmed with socioeconomic disparities, stigmatizations and from groups who possessed diminutive agency to determine the design, function and use of their community space (Bond et al., 2012, Eagle, 2015; Hande, 2018). Research indicate that individuals within neighborhood environments with markers of instability such as high rates of crime and violence were often over-represented in showing other signs of deprivation in the living environment including unsuitable, poor-quality and negative internal state of housing, air, and environmental pollution, overcrowding and neighborhood noise, which had considerable influence on the residents' wellbeing and were found to be associated with poorer mental health outcomes (Bond et al., 2012; Eagle, 2015; Shepard, 1982; Wandersman \& Nation, 1998; Williams-Goldhagen, 2017). These conditions compounded by other incivilities, social and structural inequalities would push vulnerable community members into constant states of trauma because of fear of crime (Bond et al., 2012; Eagle, 2015). This would often lead residents within such neighborhoods to withdraw and self-isolate to cope, leading to physical inactivity as a response to the complex series of environmental stressors (Bond et al., 2012; Eagle, 2015; Mitchell \& Popham, 2008). Perceptions of safety, including fear of crime (Eagle, 2015) and constant states of trauma (Eagle, 2015) influence residents' self- identity, their relationships and ability to seek supports, and level of community engagement, how they perceive and interact with others and directly impacts and informs the ability of community members to engage with agency within the environment itself (Bassett \& Moore, 2013; Bond et al., 2012; Eagle, 2015; Hande, 2018). To conclude, the socio-physiological responses of having to navigate an unstable, complex, multidimensional environment without adequate enforcement and community supports further subjugates community inclusive of those who are vulnerable and marginalized influencing 
psychosocial and health dimensions and ultimately negatively affects social cohesion, agency and autonomy (Eagle, 2015).

\section{Spatial Justice}

Spatial justice provides an important lens to critically explore the issues, specifically power and violence, embedded in the physical, structural and social environment (Eagle, 2015; Shepard, 1982; Williams- Goldhagen, 2017). Within dialogues about spatial justice there is a point made to try to unmap and unpack experiences of fear of crime (FoC) (Eagle, 2015) for all members of the community. This means mapping the neighbourhood via the person in the environment and person in the situation through a systems framework (Kondrat, 2013). Often relying on general systems, nonlinear, dynamical systems theory, social constructionism and other theoretical conceptualizations within community and environmental psychology, its discourses concentrate on social inequalities from an ecological perspective, centering on the underlying power dynamics that characterize human relationships with built, natural, social and systemic spaces (Bassett \& Moore, 2013; Berado, et. al., 2018; Bond et al., 2012; Dunn, 2002; Eagle, 2015; Garcia- Ramirez et al., 2014; Kondrat, 2013; Roundtree, 2011).

The vision and analysis within spatial justice aligns with the goal of community empowerment, aims at growing collective efficacy and community participation, and aspires to improvements in individual and collective agency and ultimately social transformation (Berado, et. al., 2018; Eagle, 2015; Graham, 2017; Norma, Roundtree, 2011; Williams- Goldhagen, 2017). Discourses within the disciplines of community psychology and critical architecture (a subbranch of architectural philosophy) (Williams-Goldhagen, 2017), critically express spatial justice as integral to unmapping space and understanding the environment. It provides insight into the non-passivity of the built and social construction and animation of space revealing its ability to 
greatly influence cognition, identity and human-wellbeing (Eagle, 2015; Hande, 2018; Shepard, 1982; Williams-Goldhagen, 2017). Spatial justice politicizes and calls space into discourses of reciprocation and social justice. In doing so, it helps to unmap the power of place (Eagle, 2015, Williams-Goldhagen, 2017), disrupts the notion of the environment being a passive aspect of our daily experience and expressly seeks to identify, address and challenge the built, social and physical representations of power and violence within space (Eagle, 2015, Williams-Goldhagen, 2017). In doing so spatial justice calls space into question which helps to disrupt the entrenchment and reproduction of social inequalities in vulnerable community settings, whether public/ private, and/ or in institutional settings (Eagle, 2015, Hande, 2018; Williams-Goldhagen, 2017).

Spatial justice leans on Freire's praxis of action-reflection and seeks to build and find ways in which to develop dialogical critical consciousness approaches (Roundtree, 2011). These theories and frameworks help focus the purpose of the discipline and research to challenge existing power structures within the concept of spatial justice. For example, a study conducted by Bond et al., (2012), critically examined the impact of housing and neighborhoods within deprived areas and the impact that urban regeneration had on the psychosocial aspects of the marginalized community. Through their inquiry, the researchers uncovered that there were no benefits determined through self-reports of those from the community, putting into question whom revitalization efforts are really for? Similarly, a study was done with a community with Vancouver residents (Dunn, 2002), which took both a critical and feminist approach in terms of the theory guiding their research and in data interpretation. Dunn, (2002), politicized the impacts that the combinations of housing inequalities and social-inequalities have on mental health, while 
researchers Berado, et al. (2018), perceived the impacts that this had on youths' purpose development seeing correlations between the environment experience, identity and wellbeing.

The majority of research which supports currents building on spatial justice was grounded on and consistently advocates for social change through the empowerment of disadvantaged groups, often from marginalized communities (Bond et al., 2012; Dunn, 2002; Garcia-Ramirez et al., 2014;). The literature also called for integrated action which addresses these social inequalities by better understanding ways service providers and communities can coordinate to improve the quality of life and living conditions of neighborhood environments (Berado, et. al., 2018; Garcia- Ramirez et al., 2014; Hande, 2018). Spatial justice if enacted through anti-oppressive, inclusive, community centred, participatory practice can be operationalized as a an act of resistance, especially in challenging the status quo concerning communities struggling with incidents of violence, poverty, lack of safe and affordable housing, and the rising amount of visible populations struggling with mental health and addictions issues (Eagle, 2015; Hande, 2018). Spatial justice goes well beyond the individual focus and integrates social, environmental, economic, cultural, political, as well as global impacts and influences in order to develop positive changes in communities with regards to navigating systems, advocating for and putting in place more neighborhood accessible programs and other environmental features which promote health, participation and empowerment at both individual and systemic levels (Eagle, 2015).

\section{Social Cohesion}

The literature consistently presented the importance of centralizing the psychosocial value found in community relationships between both humans and their neighborhood environments (Bassett \& Moore, 2013; Berado et al., 2018; Dunn, 2002; Eagle, 2015; Rogers et 
al., 2008; Wandersman \& Nation, 1998; Williams-Goldhagen, 2017). Many of the researchers took this awareness and spoke of the need for community relationships and development to be central to informing policy, city planning and guide all other stakeholders who are involved with work in the community, and revitalization efforts (Bassett \& Moore, 2013; Berado et al., 2018; Bissonnette et al., 2012; Dunn, 2002; Eagle, 2015; Hande, 2018; Rogers et al., 2008; Wandersman \& Nation, 1998; Williams-Goldhagen, 2017).

Literature also showed that when the intention is set to scale up or build safe and healthy environments and to consciously create opportunities and spaces with which to build social cohesion, evidence showed positive correlations to heightened levels of health and greater selfagency (Bassett \& Moore, 2013; Dunn, 2002; Williams-Goldhagen, 2017).

\section{Health \& Connections to Place}

The burgeoning body of international literature pertaining specifically to understanding the complexities of space and place on vulnerable populations has shown that neighbourhoodlevel characteristics influence health, recovery, agency and collective efficacy above and beyond the characteristics of individuals (Berado, et. al., 2018; Bissonnette et al., 2012; Eagle, 2015; Hande, 2018; Mitchell \& Popham, 2008; Wandersman \& Nation, 1998; Williams-Goldhagen, 2017). Moreover, perceptions of safety are built into the community environment and into cognition, which mutually reinforce each other in ways which can suppress and oppress thinking, creativity, problem-solving and impact recovery and health (Bissonnette et al., 2012; Eagle, 2015; Hande, 2018; Williams Goldhagen, 2017).

Furthermore, the literature consistently spoke to the reality that higher levels of incivility and lowered perceptions of safety ran parallel with increased self-isolation which had negative impacts on community-members' ability to access health and social services (Bond et al., 2012, 
Eagle, 2015; Hande, 2018). The literature also showed that unstable, unsafe and unclean neighborhood environments negatively impacted community-members' ability to build and sustain social relationships with other community members (Berado, et. al., 2018; Eagle, 2015). Furthermore, these harmful environmental conditions impact residents' opportunity to engage in expressing their own agency and self-determination within the environment itself (Bassett \& Moore, 2013; Berado, et. al., 2018; Bissonnette et al., 2012; Eagle, 2015; Hande, 2018; Mitchell \& Popham, 2008). The current in the discourse also spoke to the fact that people of all ages were being impacted negatively both emotionally and psychologically from exposure to these persistent negative social and environmental conditions (Bissonnette et al., 2012; Eagle, 2015; Hande, 2018; Ellaway et al., 2014; Bassett \& Moore, 2013; Wandersman \& Nation, 1998). Wandersman and Nation (1998) likened the effects of the current conditions of urban neighborhoods on mental health to the effects of toxic chemicals on physical health. Findings from Bond et al. (2012) also showed significant interactions between income deprivation, exposure to accessible green spaces and mortality.

Enviro psychology discourses spoke to the use and accessibility of space calling on the state, developers and policymakers to create neighborhoods which allow for living a good life, meaning many things including the space and thereby the opportunity to develop capacity and enhance social cohesion (Eagle, 2015); build shared narratives, find common meaning. They emphasized the need for planners to create and preserve spaces for people to be able to dream, share and vision together so that they might find united approaches to issues affecting and impacting their community (Eagle, 2015; Williams-Goldhagen, 2017). Berg et al. (2010), Eagle (2015), and Williams-Goldhagen (2017) recommended that there be more spaces for healing, 
recovery, social participation and community building within urban spaces to increase personal wellbeing and greater collective efficacy.

In downtown Toronto, however, the state's ability to meaningfully strengthen the social welfare net and expedite action on the greatest issues facing the city, such as the need for supportive and affordable housing, greater access to mental health, detox and treatment supports, and these critical supports are simply not being met (Bissonnette et al., 2012; Hande, 2018; Smith, 2011). Health and place research focuses on epidemiology and the social and physical characteristics of neighbourhood environments such as social connections and networks, perceptions of crime and safety, socioeconomic status, and a strong relationship between the impacts it has on peoples' ability to access services and the ways in which this directly and indirectly impacts health outcomes (Bissonnette et al., 2012; Hande, 2018). This shows us that access to healthy spaces and places of belonging are really public health and safety issues, ones which Toronto needs to consider and act nimbly on if Toronto wishes to have any futurity as a livable city.

\section{Gaps in the Literature \& Research Questions}

\section{Where is the data?}

At present, there is a dearth of accessible data and detailed assessments on the social, health and environmental risks present within this community, let alone any research such as ethnographies which centre community voices speaking to their own experiences. The scarcity of such data and literature on this community is reflective of a long-standing and problematic invisibility (Lott, 2002) which speaks to the multi-decade "moral exclusion of stigmatized others and is illustrated by cognitive distancing, institutional distancing (in education, housing, health care, legal assistance, politics, and public policy), and interpersonal distancing” (Lott, 2002, p. 
101) which is expressed so violently and acutely at Sherbourne and Dundas. The reality is that this has only helped to further the social, structural and institutional violence which deinstitutionalization was supposed to help dissipate. Tragically it has also reproduced and prolonged injustices and suffering to this already dense and incredibly vulnerable, highlystigmatized community. Furthermore this expression and exactation of unchecked power within this space has worked to diminish and dismiss the voices, knowledges and representations held by Toronto's most subjugated from informing academic conversations and pedagogy which sit just on the periphery of this neighborhood space.

The lack of research and the lack of resident voices from Sherbourne and Dundas community within social work and health research is starkly apparent in the scholarship. This is troublesome given that the Sherbourne and Dundas neighborhood is marked as being historically marginalized, is the site of the first social housing in Toronto, is in the same community as two post-secondary institutions, is geographically situated in close proximity to where over two hundred social service agencies have purview and is also within close proximity to multiple hospitals where multiple health service providers operate.

Many of these institutions function under a similar theoretical umbrella, with a purview founded on ideals of human rights, capacity-building, creating opportunities for advocacy, enhancing community consciousness, and so forth. However, I was only able to source two research papers which looked at different issues impacting the downtown east area, but not where residents' voices were central ( Hande, 2018; Parenteau \& Saldanha , 2013). Other than these two papers there has not been any accessible geographically specific research, other than the Metropolitan Action Committee on Violence Against Women and Children (METRACs), 
safety audits crime metrics through Toronto Police Services (METRAC, 2010; METRAC, 2014; Toronto Police Services, n.d.).

The lack of accessible data also implies that detailed demographics, needs and risk assessments for this specific marginalized community are several decades behind and that the threat analyses for these compounding socio-economic and environmental hazards have largely been essentialized and amnesticized which makes mitigation planning and galvanizing a coordinated and collaborative response extremely challenging (Eagle, 2015).

\section{Lack of Rapport and Engagement with Community}

Throughout the review across research disciplines there was also no emphasis placed on building rapport with those being researched as part of their methodology (Bond, 2004; Berg et al., 2010; Dalton et al., 2015; Wandersman \& Nation, 1998), with the exception of the study by and Dunn (2002) and Parenteau \& Saldanha (2013) the majority of research was not participatory nor sought direct and reciprocal relationships between the researcher and those who participated. Although Hande (2018) spoke to critical disability and opportunities for activism in the downtown east, she spent the majority of her communications with service providers and not engaging with the people in the community who are really on the frontlines, meaning there was still a chasm of voices that needed to be sought out and amplified.

The sharing of personal and community- level, place-based information can legitimately increase the risk and vulnerability of participants, especially if it challenges the systems and entrenched power structures that have rooted themselves in these spaces. In light of this it was important as the researcher that I commit myself to making sure that this information I was extracting would give back in meaningful ways. In general this is vitally important to consider in any community based research and/or venture within marginalized communities given the 
amount of career and identity building, both personal and professional, that the researchers and agencies alike receive out of the exchange which often is largely one-sided. It is also important to acknowledge that academic institutions and their funding partners are essentially the biggest stakeholders and benefactors of community based research and so the social benefits need to be moving downstream in terms of impact and challenged when they do not. This means that there needs to be a greater commitment from researchers who go into these spaces as well as the institutions which sit on their periphery of these spaces to commit to fortifying and supporting these vulnerable communities for greater social change (Kovach, 2009), and data collection is certainly part of that. The researcher Margaret Kovach (2009) whose work is grounded in an Indigenous methodological lens' warns us that we should not be working with any community, especially marginalized ones if all we seek to do is extract their bodies and information and then leave without reciprocating the gift (Kovach, 2009).

\section{Showing up to give back}

It is apparent that the Sherbourne and Dundas community needs a multitude of intersectoral, collaborative pilot and research projects performed in order to help support, inform and even demand policy, practice and programming changes from the local to the federal level. This means developing research which is geographically -specific and community- informed so that the data is rich and the information yield returns insights which are tenfold. Detailed demographics need to be gathered across all measures, analysis of metrics and performance of risk-assessments across all determinants beginning at the hotspots and moving outward need to be performed, scaled up and re-performed as the environment and the density which impacts is constantly morphing and informing it. Through epidemiological and ethnographic research quantitative and qualitative data will begin to emerge so that there will be a more inclusive 
environmental assessment from which to contextualize, identify and address some of the complexities and impacts of persistent crisis that is influencing the agency and wellbeing of residents who live here (Eagle, 2015; Williams- Goldhagen, 2017). In parallel to this interprofessional research there needs to be a joint commitment to perform dialogical research and run pilot projects with community members so as to inform new levels of coordinated action and to create a pool of shared meaning from which aligned action can transpire (Isaacs, 1993).

In short, the Sherbourne and Dundas community needs to have research which is inspired and driven by the desire to assist this vulnerable and complex community while also having research which is being informed by the community. Statistical studies are an important part of this, but in order to unmap the power and violence that is experienced, witnessed and expressed its many manifestations at Sherbourne and Dundas the research needs to be informed by community perceptions and centre the specialized knowledge of the space held by those who live there (Isaacs, 1993; Kovach, 2009; Lafrance \& McKenzie-Mohr, 2017). Research from the Sherbourne and Dundas community can be used to increase community wellbeing, rekindle a resurgence and move neighborhood residents and the city towards reclaiming their community spaces with increased social capital, safety and stability for all (Kovach, 2009; Lafrance \& McKenzie-Mohr, 2017). This research can also greatly inform other major cities with communities experiencing similar issues in providing insights on how to address public health and safety concerns and assist their residents and other stakeholders in building resiliency and mitigating crisis.

It is for all these reasons that this study aims to contribute to helping the people who live at Sherbourne and Dundas in reclaiming their neighbourhood spaces and making their voices central to helping define and improve their experiences of their neighborhood space with the goal 
of enhancing their health, recovery and quality of life. In doing so the study sought to answer the following questions:

- What are the impacts that the community environment has on the wellbeing of those who live in the urban neighborhood of Sherbourne and Dundas?

- What does their embodied knowledge and experience reveal about what is happening in terms of ways in which they experience this environment over time?

- How has this environment formed and influenced their emotions, identity and perceptions of themselves?

- What do they see as necessary to transform and reclaim these spaces for greater wellbeing? 


\section{CHAPTER 3: RESEARCH METHODOLOGY-STORYING \& RE-STORYING}

Narrative place-based inquiry was chosen as a methodology for studying the lived (ing) experiences of the community members at Sherbourne and Dundas. Clandinin (2013) who developed methods for NI, described the researcher as being "in the midst" (p. 203): in the midst of life, the lives of the neighbours, the community and the larger social political and environmental context of a larger interconnected relational world (Clandinin, 2013). Appreciating this influenced my research to place emphasis on the importance of relationships with people and their reciprocal connections to the environment. Many European pagans and Indigenous people hold relationships to humans, non-humans, the Earth and beyond this realm as sacred and there are many protocols and ceremonies, medicines and teachings which nurture, teach and honour all of these (Corbiere, McGregor; Migwans, 2013; Flowers, 2016; Kovach, 2009; Roesdhal, 2016; Shepard, 1982). Stories are important vessels for sharing knowledge, wisdom and insights, even unpopular ones so that the truth may be carried forward to shine light into the future. This is the intention I set before entering into this community, and it's one that I hope that we all as researchers honour before engaging in community-based research moving forward.

This dialogical inquiry afforded by NI invites community members into a space of sharing one's story encouraging them to participate in a pool of shared meaning (Isaacs, 1993) and co-constructing of knowledge (Kovach, 2009; Lafrance \& McKenzie-Mohr, 2017). The sharing of their living memory was vital to this research (Kovach, 2009) and is a cornerstone of collective learning that can lead to transformation (Isaacs, 1993). Given that this neighborhood has a history of violence and tension I chose this approach in order to honour the voices of those marginalized who live here and was influenced by Margaret Kovach's (2009) Indigenous-based methodological approach to centring community members' voices and honouring the 
relationships forged through the intimate sharing of living experiences (Kovach, 2009). Narrative place-based inquiry also provided me and all those who gain access this paper an unprecedented insider view of the currents of complexity and challenges experienced daily by those who live in this neighborhood environment. The narratives shared in this paper are part of this community's continuous fierce acts of resistance and resurgence in the face of many challenges. The placebased dialogues provided a safe space for inquiry whereby both the participant and the researcher could reflect together. This methodology was a perfect fit given that oral histories do not form themselves neatly into structured questions or conventional boundaries and in this freedom the community members were able to share and freely share what they know (Kovach, 2009). In this way, the process proved to be a pathway for community members to reclaim space in their own neighborhood, unmapping their experiences and their neighborhood's geographies in their own words, representations and perceptions. Through this dialogical inquiry of co-creating knowledge there was transformative potential reciprocally exchanged throughout.

\section{Recruitment \& Participants}

The study was open to anyone who lived in the Sherbourne and Dundas community from the ages of nineteen to ninety-nine living within the following limits, Gerrard to Shuter and George Street to Ontario Street. There were no other restrictions. I had already established relationships with some of the community members and had asked someone who was wellconnected to the neighborhood as a resident to hand out fifteen invitations to various community members for the opportunity to participate. I did this knowing that I was only planning on interviewing three people, but this increase in amount of invitations helped to keep all those who contacted me unknown to the initial contact from the community, to preserve their anonymity. I collected demographic data, names and phone numbers from participants, solely, to be able to 
contact them for interviews and to set up the interview. The numbers and names were deleted after the interviews were completed. Each of the participants have my contact information to contact me after I submit this research so that they can have it for their own records and for their future community advocacy work. All names and identifiers are not included in the transcripts and false names have been given in place of participants' names and those who were part of their shared narratives.

\section{Data Collection}

I conducted in-person, semi-structured (Seidman, 1991), and in-depth interviews (Creswell, 2013; Johnson, 2001) with three members of the Sherbourne and Dundas community. These members' stories are introduced in more detail in Chapter 4. Gathering through one-onone interviews with community members, a collection of insights and incarnate knowledge organically emerged within each of their own accounts. This process helped to unearth and highlighted the perceptions of what they saw as most impactful on their experiences living here. These discussions also helped participants from the community to clearly identify what actions they saw needing to be realized within their community to improve safety, stability and quality of life (Lafrance \& McKenzie-Mohr, 2017). Sharing their experiences of their environment in real-time and over time gives us incredible insight into how different places, agencies and actors carry power and influence community members' view of themselves and the ways in which this impacts and influences their daily movement through space. Community members' accounts can also disclose how cycles of violence, power and social-dissonance are (intentionally and/or unintentionally) permitted, re-created and perpetuated whether through built spaces, internal or external systems and imposed structures within urban community environments (Isaacs, 1993; Shepard, 1998; Williams-Goldhagen, 2017). 
Without the power of open community dialogue and the creation of spaces to engage in this critical work to build a shared understanding, we may very well be implicated or complicit in hiding, missing and/or dismissing (Isaacs, 1993), the opportunity for innovation and enhancing the quality of community spaces for greater wellbeing. This research methodology and the submission of this MRP conferred the opportunity for an opening in the ivory tower for these community voices to enter and pierce the academic realm, and hopefully well beyond, so their voices, living stories, and their knowledge will be shared without interruption. It is hoped that this paper will increase the pool of shared meaning in understanding community wellbeing and lead to new levels of coordinated action (Isaacs, 1993).

I met with the participants in locations within their community which were private and chosen by each of the participants. I expressed the purpose of the research within the delivered flyer script (please see Appendix A), and provided each participant with a copy of the oral consent (please see Appendix B). We went through the consent and I made sure that the participant understood the meaning of the process and made it clear that they were free to withdraw consent at any time until the set date of May 1st, 2019. Finally, I provided them with my number and email should they have any questions or concerns and need to contact me.

With permission from the research ethics board (REB), I used an oral consent transcript and received oral consent from all participants. The rationale for this is that the community with which I am conducting the research has been both acknowledged by the City of Toronto as being a marginalized community and has also been historically recognized as one with great saturation of poverty and other indicators of social and economic inequity (Government of Canada, 2017). Centring community members' narratives as my primary source of information meant needing to put in protective measures for those who participate, especially given the history of 
marginalization and exploitation that many members of this community have and continue to suffer. Ethical considerations and limitations, including anonymity, were in place from the beginning and remained throughout the research process.

During the inquiry, I used an interview guide, not to restrict the natural flow of the conversation, but to assist me and the participant in keeping track of the conversation and in order to honour the time of the community members for sharing their insights with me (please see Appendix $\mathrm{C}$ for a copy of the interview guide). The sharing of their stories could have potentially brought up accounts of trauma and other triggering emotions. To mitigate this, I was clear in the beginning with the consent and gave subtle reminders throughout the interview process' that participants were welcome to stop the interview at any time should they wish to take a break or no longer proceed. I also provided each of the participants a list of local community resources including crisis and mental health support counselors for extra support (please see Appendix D for resource list).

\section{Data Analysis}

Analysis of the social, systemic and built environment was embedded within the narrative inquiry process held within this framework through the lens of critical social theory with the aim to involve, arouse and centre the residents' knowledge, securing their expertise in identifying key safety and accountability issues in their neighbourhood environment. Through this conversation I worked with them to unmap the experiences, structures and contradictions within their community environment's space. This methodology allowed for the residents' voices and representations to be central in identifying the neighborhood's structures and to set their own priorities relevant to their expressed concerns. 
I also used a thematic analysis post inquiry to unmap these shared neighborhood geographies via the questions I chose. The qualitative data was analyzed using coding techniques to extract the residents' identified environmental representations as the key knowledge holders of their neighborhoods. This approach to the analysis helped disrupt the dominant narratives of agencies, academics, including myself, and the structures which are usually provided and afforded the space and power in presenting this vulnerable community's story rather than having their very own space. Their stories were then analyzed for common place-based representations through the themes that each participant brought up in the wells of their knowledge sharing.

I reviewed the theories which inspired my questions for this research and then re-read the transcripts looking for all of the meaningful connections and currents which intersected with the theoretical lenses from critical urban theory, spatial justice, community and enviro psychology. My research sought to encapsulate these experiences into a pool of meaning by coalescing these representations within the veins of these theories. The entire analysis of these embodied stories was critically and respectfully engaged in order to build the community's praxis of resistance as these community impact statements are part of an ongoing act of resurgence for both the land and the people.

\section{Research Limitations}

The clear limitations would the length of time for the research study, which was one month for both recruitment and interviewing and one month to put the research through theory and complete the findings for the MRP. Other limitations placed on this research were based on participation. The amount of community residents I could interview was set to maximum three, given the requirements to complete the research and for the required length of the MRP. An expansive study of a larger and more diverse set of participants within the Sherbourne and 
Dundas Community would allow for a deeper examination into life situations that conceivably affect the experience and impact of the environment on community members. Furthermore, the limitations to amount of participants meant that this research presents just three narratives, a drop in the bucket, given the depth, density and complexity of living stories in this neighborhood. Although I am incredibly grateful and honoured for the interviewees imparting and gifting me with their knowledges through stories, this only presents a small part of the great range of insights and testimony that this community has to engage with and offer.

Finally, limitations were set by the fact that my academic knowledge in the theories applied are quite novice, although my experience with them and this community quite thorough. There has been so little research done with and within the Sherbourne and Dundas community, which means I have just begun to look at a pebble which sits on this mountain of data, which also offers opportunities for further research and action which can increase capacity building for this vulnerable community and drives its transformation. I encourage anyone in any direct or related fields and disciplines to continue doing research with this community and to dive deeper and expand on any of the insights and theories that I have espoused, but only in a way which uplifts and honours those who have had to live here. 


\section{CHAPTER 4: FINDINGS- THREE STORIES OF THE NEIGHBOURHOOD}

I begin this chapter with the introduction of the participants of the study through their stories. The study sample consisted of three participants who were all recruited from the neighborhood of Sherbourne and Dundas, in Toronto. The sample though small, represents a diverse group in that have all resided within the neighborhood for over five years and included two participants who had resided in this location for over twenty years.

The first participant, Alice, is a 57-year-old woman who is a mother and grandmother, and works full-time. Alice has been working to take care of herself and her children and grandchildren since she moved into this neighborhood in the eighties. She has been active in trying to make her community safer and more welcoming for her children, grandchildren, herself and also for the other families and children in the neighbourhood. Alice tries her best to participate in neighborhood events, resident meetings, neighborhood organized clean-up initiatives and continues to do positive acts to reclaim space.

Gavin is a 50-year-old male who works regularly and has been raising his son in the Sherbourne and Dundas community since his son was a young child. Gavin also lived in the area as a vulnerable youth since he was in his mid-teens and has seen many changes to this community over that time. As a person with living-experience, Gavin has been a champion in his community devoting well over a decade to doing advocacy work on behalf of the families, vulnerable residents, the homeless, and his neighbours who live here. He does so by sharing information, providing friendship and other much needed supports without any expectation of repayment. Gavin has created and run neighborhood programs and events in his community with the intention to build relationships between all the neighbours and families. He has also worked with multiple local agencies forming and running innovative peer-led programs directly benefiting the wellbeing and capacity of the community. 
Jackson is a 42-year-old male who works tirelessly in his community doing volunteer and advocacy work on behalf of his neighbors and the community at large. He has spent many years and countless hours attending meetings and conferences, sitting at tables, being part of associations and lobbying for extra supports and interventions for the community's most vulnerable. Jackson has worked with his neighbors and other community members to facilitate community-driven food programs, co-hosted social events and formed a neighborhood-led group to improve safety conditions of his entire building residence. Jackson is a resident whom many seek for support, get directions on how to navigate systems from, and is someone who many within the community of Sherbourne and Dundas trust.

I will present the findings of the narrative inquiry process through an overarching framework of theme identification created by Clandinin and Connelly (2000), which emerged during the interviews with participants in this community. These interviewees' stories are considered living accounts of this specific social, structural and geographical land and place; also providing clear transmissions of the ongoing and compounding impacts which have come out of daily engagement with and in navigating this space. For this particular type of research inquiry it seems very fitting to use Clandinin and Connelly's thematic framing (2000) to extract major themes, or commonplaces, which are reflected on through the lenses of temporality, sociality, and place. Below I have outlined brief descriptions of each theme which then have been interwoven with the testimonies of the community residents interviewed, as the embodied living stories of the Sherbourne and Dundas neighbourhood environment. As will be apparent in this chapter, I present large excerpts of the interviews so as to maintain the coherence of the stories and also to stay as true as possible to the participants' narratives. In Chapter 5, I bring the 
narratives, scholarship and my own analysis together to offer discussion and implications of this study.

\section{Temporality}

Temporality denotes and acknowledges the fluidity of time (Clandinin 2013; Clandinin \& Connelly, 2000). It considers the "when" of people's stories; as they weave together in nonlinear form revealing the unfolding of living experiences, wisdom, insights of the community through story-telling (Clandinin, 2013; Clandinin \& Connelly, 2000; Kovach, 2009). What my research intends to make clear is that many of the residents living here at Sherbourne and Dundas hold a type of specialized social and structural- ecological knowledge both in retrospect, from being long-term residents and as living, emotional and thinking human beings experiencing and mapping this particular space in, through and over time (Shepard, 1982; Williams-Goldhagen, 2017). This is an incredibly complex and diversified neighbourhood (Brillinger, 2018; Toronto Community Housing, 2018; Bailão \& Wong-Tam, 2019) of vulnerable people in which from one moment to the next is incessantly evoking the senses, demanding and/or precipitating cognitive, physical, emotional and biological responses (Williams-Goldhagen, 2017).

Analogous to the buried rivers shaping and carving the ground beneath Sherbourne and Dundas neighbourhood, the reciprocal influences that this environment has on the people who live have and continue to shape and influence their living-paths, including accessibility and opportunities to both space and the ability to activate one's own agency and self-determination have clear and serious impacts on health, wellbeing, quality of life and dignity, all key tenants to social determinants of health (Anakwenze \& Zuberi, 2013; Bassett \& Moore, 2013; Berg et al., 2010; Bissonnette et al., 2012; Brown et al., 2005; Dunn, 2002; Eagle, 2015; Shepard, 1982; Williams-Goldhagen, 2017). 
As we shall see in more detail in this chapter, Jackson, Gavin and Alice's stories are the living embodied ecological knowledge of this multifaceted neighbourhood space. Their insights and knowledge help inform and illuminate the complexity of intersecting relational and structural influences that the Sherbourne and Dundas environment is having on their minds, bodies, identities and life paths.

\section{Place}

Place, as a second major theme or commonplace in this narrative inquiry, is the 'where', or situated- place of inquiry (Clandinin 2013; Clandinin \& Connelly, 2000). The stories of Alice, Jackson and Gavin primarily occur within a one block radius of Sherbourne and Dundas. Especially noticeable in Alice's and Jackson's shared narratives, is how this environment has reached, even trespassed daily into their place of dwelling disrupting them, their family, friends, from trying to find some peace, perhaps even just a space to recover at the end of the day.

Alice relates some very personal and tragic experiences that affected her and her family. In her accounts, Alice shares how the changes in the environmental conditions within this community have impacted her and how she and her family engage with their neighbors and the physical space. As a long-time resident, she also provides insight into how these imbalances within the environment impact the ability to move through and be present in shared spaces. Alice also speaks to the systems and power brokers in place within the community which hold considerable power in the environment, even just steps outside her door. Alice then shares how living at Sherbourne and Dundas has impacted her family and how she sees herself being able to influence her neighbourhood environment, how over time and the many experiences she has had in this community have shifted and influenced how she engages with the surrounding neighbourhood. 


\title{
Alice's Story
}

Interviewer: And how did you find your community and building in the eighties and nineties?

Alice: Yes. Very nice, very nice

Interviewer: When you did report issues, was everything better? Such as the state of the building?

Alice: Everything was better, the building, the people were better. The kids used to run free. It was really beautiful. It was 1986, I think. I lived on a higher floor. It was really nice then, and the building we lived in was under a different name. Upstairs we had our first child; and then we moved down here within a month; cause it was so easy to transfer from one unit to another. Now, it's like pulling teeth.

Interviewer: And how has this living in this neighbourhood environment impacted your children's' ability to move through the space. As you had said you were telling your children that they had to be safe, that they had to be home on time, but have there been instances, if you so choose to share that have impacted ...

Alice: Well around here (my child) got attacked, raped.

Interviewer: And how old was- when that happened?

Alice: In their 20s. Meeting with the wrong people at the wrong time, you know ...supposed to be their friends

Interviewer: It's hard for any mum. Did anything come out from it?

\author{
Alice: No
}


Interviewer: Nothing-is it because you can't and that you're living here? And...?

\begin{abstract}
Alice: yeah
\end{abstract}
Interviewer: Are they still around?

Alice: I don't know. We don't see them. It was in the dark. (Her child) was coming home in the laneway. So now (my child) just stays in. - will go out with her friend. I guess it's still in (my child's) mind. So you got your good and you got your bad. It's mostly bad.

Interviewer: So, are there any places you have to avoid in your neighbourhood? Alice: I still don't go into to [building number]. I am petrified of that building! Interviewer: So do you find that you've had to change your patterns of walking? Alice: At times, when it's light out. When I come home from work, at - or - in the evening. If it's light out I will take the laneway. If I notice a whole bunch of people on the street in front of the building, I just walk up (the back) and come down that way. Especially on cheque day, you try to stay away. It's sad, because if you have a buggy full of food or something, there we have many stairs to come up, to try to pull a buggy up there is hard. So it's easier to come up through the front, because it's flat and come. Sometimes on cheque day you don't want to do that.

Interviewer: When did the gathering at the front entrance begin?

Alice: Years, years ago

Interviewer: More than 5 years?

Alice: Yeah

Interviewer: So they very much feel like that's their space? 
Alice: Yeah. The guards used to smoke out there with them, have coffee out there with them. The guards ain't supposed to make friends. Like I even know some guards, like the ones we seen walking down, that person knows everything that's going on around here, and who got hurt, who fell of the balcony, who....the guards tell her. To me, that's supposed to be private. So I don't even phone the guards because if you think the guards are going to tell whoever you phoning on, oh it came from this unit, so why even bother risk it. Right?! I know that my neighbors are neighbor from hell and I am stuck here. So now I don't care what happens. I don't care. I put ear plugs in at night and ...even with the shooting here a couple of weeks ago or a month ago, in the back lane nothing was done about that. Then there was another shooting at the park (child's playground) in [building number] on the other side of the place. The cops never asked anyone what happened; they didn't ask us if we saw anything.

Interviewer: They didn't do any inquiry?

Alice: Yeah

Interviewer: And there was no follow up counselling for the kids or?

Alice: No, no

Interviewer: So I guess we can go further into that kind of stuff. What other crimes have you experienced, heard, sounds?

Alice: Shootings, stabbings, fighting over drugs. Up on the higher terrace where they walk nothing but fights, and arguments. 'Give me my weed!', 'Give me my dope!', and that's what gets me. I remember years ago, when City Homes was here, if you sold weed, you get 
evicted immediately. Now they can do whatever they want. They could take over your units; they could do what-ever! And nothing gets done, you know. It's sad. If they want to try to clean up around here or around wherever start with the housing first.

Interviewer: Yes unit takeovers are a big deal and $\mathrm{TCH}$ is aware which units are taken over

Alice: And nothing gets done! Nothing gets done. Needles, crack pipes, pipes, or bodies. Just last summer a body came out of the window facing the playground at the park.

Interviewer: So what was the follow-up with that, because that's very traumatic?

Alice: I have no clue, no clue. I have no clue about the shooting a couple of years ago. I know those kids had seen by the park, and the parents were running. And nothing (was done). So, like it is sad".

\section{Jackson's Story}

Within our exchange, Jackson notes more than several occasions in which the outside environment has pierced the only safe place he has, within his private dwelling and reveals how this impacts him socially, psychologically, emotionally and physically. From these near- decade long experiences in the environment after being institutionalized Jackson is able to offer his knowledge and specialized insights from a mix of self-reflection, information building and skills he has gained from trying to cope and do advocacy work here.

Jackson: I spent 10 years in solitary confinement, and six years of population, and the complexities of prisons, seeing how various racial groups interact. Even personality types within those groups, how they coalesce within different factions, as far as gangs, and then 
what their objectives are, and then the broader questions of race that exist within prison. It's a complex dynamic to navigate. There is a clarity there, because there is some sort of objective rule. And I would have to say that, in contrast, having a middle-class background coming into Dan Harrison, but having the prison experience, and being able to see that, you know, there is a baseline of what social normality can be, and that other people have different baselines, of social normality, and what those behaviors want to become the end result of what their social norms are. And to see Dan Harrison in comparison to prison, and know that it is public housing, in a city, of province, in a nation that extols itself on virtue, and you realize that there is no virtue at Dan Harrison and the people that have dealt with it have ceded any responsibility for decades. We'll get into what exactly I'm referring to a little bit. In that there's even within prison within, within the US prison system, and whatever stereotype and prejudice you want to apply to that, because I mean, it is certainly well received, and deserved given the history of the US prison system. There was accountability there. There was professionalism there. And when people, even if it was contrary to some of the corruption that existed within the US prison, the prison system, stepped up and did the right thing. They were punished. And what I've observed is that in relation to Dan Harrison housing, and the whole Sherburne and Dundas, and it relates to social workers and as it relates to police, it relates to people in the City, that when you stand up and you say the right thing, or maybe it's the wrong thing, about that neighborhood (Sherbourne and Dundas), they get punished. It's bizarre that, that I've seen it happen in five years, in different forms in fashion. But yet the people that are perpetuating the situation that exists there, they continue on their place, and like, nothing bad happens to them, they sometimes even get rewarded when they're quiet, and their present at 
something. And then, next thing you know, they've got a high paying job, or they might get moved up from security into CSU (Community Safety Unit), which you're talking somebody getting paid $\$ 15$ an hour is now going to a steady salary paycheck with a Unioncomponent. That's like $\$ 40,000$ a year. You know, so of course, you're going to be quiet.

Jackson: There's you know, I've heard people being stabbed and thrown off the third floor (in the building). I have heard people, drug interactions going wrong, people reacting to their drugs, drug deals, gone wrong, people breaking into units, people extorting collecting money from, from either fellow prostitutes or their pimps going after them, collecting money, relationships going wrong, drug relationships going wrong, in which the main thing that brings people together is the dope and then for whatever reason they fall out. And then this can be either people being stabbed, beaten, clubbed, sexually harassed, racially harassed, I mean, it runs the whole entire game, and it doesn't stop. And then on top of it, a lot of the residents that do live at Dan Harrison feel that as soon as they come out their door, rather than talking in a normal, interactive, conversational- level that people would have within five feet, they talk as if they're hollering at each other from now 1000 yards. And because it's all concrete, nothing absorbs the sound, so that that filters into the units. Then you have people that are engaging in drug trafficking, or sex trafficking all night long, slamming doors, in the individual houses. So, then that reverberates you know. So, if you have your windows open, you're going to hear it all. You then have any fire anytime fire alarms going off, you can hear echoes through the through the courtyard.

Interviewer: How many times do they go off? 
Jackson: Well, sometimes they gone off as many as three times in a day, but you're at least going to get them to three times a week tends to escalate. I think near the near cheque day. There's more drug activity. Usually it's in [building number]. But it just all that does is reverberate up into the corridor. And then you know, three o'clock in the morning, you have Toronto Fire Service comes on the speaker and says 'This is Toronto Fire Service. Stay in your unit'. So, it's like you weren't awake before, you certainly are at that point. So that's pretty much continuous. And then anytime that they're driving through the neighborhood that'll that goes through the building. And then on top of that, if there's anything taking place out on the immediate street that echoes into the building, and because usually does somebody gets burned for dope. So, then they're arguing, arguing or yelling somebody in the courtyard or the building. And so that doesn't, it just doesn't stop, there's just pretty much continuous noise.

Interviewer: like that, do you feel that that's impacted your ability to heal? And considering there are many other people for living in the building that are also coming out of transitions from domestic violence and other life situations. How do you find your calm? And do you think people are disrupted from getting that peace?

Jackson: I would say that. Yeah, me too, keeps you in a hyper state of alertness. Even in prison, you had a window every night where it was quiet for a period of time even in SEG (segregation), even, even in on the psych- patient wings, there will be a period of quietness and a Dan Harrison, it's never quiet. So, it's constantly soon as you get to settle in, you hear something and you're like, what is that? What is that?! it's like it even, even if you're not overtly in overly aware of how acutely tune your senses are. If you've been in any state of traumatization, and as soon as you're hearing something is ...Yeah, your body's going to 
react, you're going to you're going to twitch, you're going to move into it and you're going to get into that modality of behavior. So being able to fight that is very difficult. And that's why I think there's a high propensity for people to self- medicated at Dan Harrison, because in order to deal with the continuous, not, not just the violence, because it's like, even if the violence doesn't touch you there, but you have been touched by violence before, that continuous affirmation of it through sound, through sound alone. But then on a on an emotive level, you can tell when things are bad there, you can feel it, you can feel it in the air, you can feel it around people, in even if you walk by every episode of violence or horror or decay that takes place there. I mean, like, there's not to be morbid, but you know, when you're coming, you go buy a pack of cigarettes at the corner store. And when you're coming back, there's an ambulance, cop cars.

\section{Sociality}

The third major theme is sociality: the context of each participant's individual life which includes both their internal and external relations and interactions with the world, in this case community environment. The internal relationship of sociality as Clandinin and Connelly (2000), explain includes the personal or inner environment-conditions such as hopes, desires, feelings, worries, moral perception, and how they engage aesthetic. The interviewees speak of internal changes in their ways of being, and the weighty influences that the neighborhood environment has had and is having on their sense of self and purpose as well as to their ability to heal and recover. Below, Gavin discusses his return to the community as an adult and as a resident.

\section{Gavin's Experience}

Gavin: As soon as I came back all I wanted to do-I felt like they needed so much! These people were hungry, they were starving, they were robbing and stealing because they were 
being robbed and stolen from. Their cheques, the keys, their fobs, they're under house arrest, you know-like their own (house arrest) from the dealers (unit takeovers), I was under house arrest from here, but I got to go out. They (other tenants living with unit takeovers) get to (only) go out to bring in customers, they're hooked- so now the guy's hooked, yeah they're hooked on stuff. I am trying to stay clean, get clean; you know I had a really bad history of it. I did it here, so, the police say I had more will power. I tell 'em that's BS, all you got to do is fucking open up your eyes. Why are all of you scared?!! Why is housing (TCHC) and all of them scared?!! Why are the cleaners (scared)?!! Why is everybody fuckin' scared to walk down here, ride their bikes, and stop their car?!! Oh oh because there's people here there, there, running in the street. It was 6-700 people squatting in all the basements (years ago). It was out of control!

Interviewer: was that in the nineties? 2000s?

Gavin: I came here over ten years ago. --was 9, 10, so that was twelve years ago"

As a youth out of foster homes and institutions, as an adult survivor of abuse and neglect, as a resident in one of the most violent and impoverished neighborhoods in Toronto Gavin's response was not to give up but to protect what those who he saw as his extended family through helping his neighbours build healthy connections, friendships, identity and support them through advocating on their behalf and find ways to build his own and his neighbours capacity and agency.

\section{Jackson's Experience}

Interviewer: How would you say that this place has impacted your wellbeing? 
Jackson: Well, I would have to say that like for anybody that's really institution, has been institutionalized at any point. It is because it doesn't have a positive dynamic, that the architecture of the place is very similar to institutions. And because it's, everything I do is all within one space. So it's like I sleep, eat. I mean, like, I don't have to use the bathroom in the same space. Yeah, so you don't you don't transition from one room to another, so remains this very cell- like. Yeah, it's very cell-like it doesn't, I don't feel like I really left prison. The only difference is, is that I don't have a cellie anymore. So I've got like a deluxe cell that I've been can turn out and go out to the yard and visit with the rest of the inmates there. And like in a lot of people, are like inmates, it's, they're not really. Their life doesn't extend beyond that place. And a lot of them are just waiting to die, and medicating themselves along the way, and that that's....In prison, you saw people who at least had a yearning to be free and recognize even people that knew that they weren't ever necessarily going to get out. They had this fire in them, to achieve something different. And it's, you don't see that, at Dan Harrison. You see, most people just succumb to this... succumb to apathy, they succumb to low expectations, they succumb to that this- is the way it's always going to be because well, that's just the way it's always been. And it's, it's daunting, it's far worse than any prison bars. You know prison bars, you can look at them, you can observe them and you can you can defeat them, if you can see them mentally. And in there, because there are social engagements between people that are positive. But in the main, the main social, social interactions between people is, is one that's in relation to drinking, drugging prostitution, gossip about others. Negative gossip, not even just not, not the positive gossip. Oh, you know, something cheerful, it's usually like, 'Oh, they got a T.V ', it's petty, but it's never affirming. You don't find that much praise there. You know, five people really try. 
What you do find is in those moments of crisis, that people are there to be kind to each other. It's just the resonating frequency of their day to day activities is really in a negative moment.

Interviewees relate their compassionate practise of being mindful of suffering beyond their own in a way which has allowed them to focus on advocating for others and the entire community in the face of violence, stigma, shaming and other efforts to silence them in the continuous and entrenched abuses of power within this neighborhood space. Gavin, Alice and Jackson share more insights below in this regard.

Gavin: When Jack and Crystal, two residents, helped out at the resident meetings and (a new resident moved in a joined)-he came in when I needed him, only because of him and I wasn't saying anything else, because I quit, I had it up to here and beyond! I saw the way he talked to the other tenants in the resident group, he was good, everyone else was calling him a racist, a Nazi, a bigot, a homophobe,- bullshit! Bullshit! The guy is so fucking smart, he is so poetic, and you know he is so politically poetic you know! He been sitting there studying and listening, and so now it's just like for verbatim and everyone is like- whaaawordstruck, by him, 'what did you say?! I had like four years of university, and he just said two words in the same sentence; and I didn't understand it. Like is said to the new resident, 'see I told you-'you came out, and I am going to give this (advocating at the building) to you, it is a lot of responsibility, you know, don't fuckin let me down.

Alice: I got a pack of files and reports like that and it ain't working! When I used to 
participate (in resident and community groups) and ask for help they kept saying I was racist. We ain't racist, so how can we be racist. So I am glad that new people have shown up to lead at the community meetings. The problem is that our neighbors are idiots. After years of listening to that. One of the neighbour's boyfriend walks around with a bullet proof vest, so what is that?

Interviewer: It's not like you can wrap your house around with one (bullet proof vest)

Alice: No. So, we just stay and sometimes sit outside

Interviewer: So what would say, what are concerns for safety and wellbeing in the community, and in the future?

Alice: Now I think the guards should start doing their jobs for number 1 and housing should start cracking down on the people who have taken over all the units and its mostly at [building number], not this TCHC building. Yeah. So if they start cleaning it, and start bringing people in who deserves it, you know it will be a better place. Because it's not like a 700 unit place. you know, start cleaning it up, start evicting people who ain't supposed to be living there, number one, you know. Especially that park, how it the world could you let your kids go down into that park?!! years ago,(+20 years) it was beautiful, when-- was baby ( $\sim 20$ years ago) they had swings and a nice slide, you take a picture of (today) that and the garbage with they'll say how the hell could you let a kid go play in there?!!

Furthermore, Jackson shares his own reflections, expert environmental knowledge and hopes for how he would like to see the people in this community and those living in social 
housing get supported. It is clear that he is deeply passionate and knowledgeable about best practices and knows his neighbours and the environment very well.

Interviewer: So how do you think that as somebody who's been living there for a long time and experience with these different agencies, how do you feel moving forward that the community itself would benefit most from like, would it be more community-based programs, like community-run stuff, it's enabled by city or like, we're, we're agency step back, and just like....

Jackson: Okay, so like, you have to two things in capacity. What is the capacity of the community? And the capacity of the community is you have a lot of people that are illiterate, you have a lot of people that are technologically-illiterate, you have a lot of people that are socially, I don't want to say socially- illiterate, it's that because their skill sets are honed within very narrow parameters, their skill sets are very good. It's just that they that conceptually, they hadn't been brought in. So then what, in order to be able to deal with that you have to have service providers, now you gotta people that give a fuck, that that's what the issue is, you got to have people that are professionals, in people that are professionals, professional, "professional”, my compassion, I mean, like, I don't, it sounds too can, but you need something on that medical level, you need people that are going to be there, because they want to be there- not because they want the paycheck. And that and they have to be able to have the skill set to be able to identify trauma, they have to be able to figure out how to establish rapport and be able to deal with it, they have to be able to figure out how to deal with their own vicarious trauma from the being in the environment. So, it doesn't become a reciprocal dynamic. And I don't see any service providers in that 
neighborhood. They all have the politicized agenda. The service providers that I see, it's just like any prison gang too it's like, yeah, the gang has a purpose. But usually, it's the gang is only as good as the three or four good people that are inside that agency, and then they were the gang. And then what happens is, those three or four people inside that agency are going to get burnt out, because they're carrying the load for all the people that are just they're collecting paychecks. And because of that, I don't want to. Yeah, there's no fucking accountability. None these people are accountable for jack shit! You have a bunch of people that are patients! You have a bunch of people that don't have agency! and they're allowed to be fucking preyed upon. And the agencies make money off that because they're collecting money to sit there and make sure that these people that don't have fucking agency are there every day. So the drug dealers can prey on them are there for the next paycheck! Oh, well, we've lost another three this month, well, let's fill in another three bodies, get them out of the shelter in there. So that way, the drug dealers can get their paycheck easy, and maybe they might be able to get a new unit to take over. So, no, I don't .... what they need. They Yeah, they need people to care. They need to they need they need health -care model. They need to be able to sit there and have the legal authority to be able to make decisions for people that are in crisis and that are especially if you're coming maybe you're bombed out on meth, you're bombed out on who knows what fucking chemicals they put in the dope. And then suddenly, because you know how to play the game, you're able to slip through the cracks so that way you can get back out on the street and then get abused and raped again. Well then do so obviously the whatever the institutions are offering, they don't want to partake in that and it's safer for them to be out on the streets around the other shit, which is very telling. 
External socialities, as Clandinin and Connelly (2000) describe them, are the outward existential conditions, of both the built and social environment, which comprise the matrix of relationships, interactions and engagements influencing and adding to surrounding factors and forces, including people, sounds and otherwise, which can inform and influence individual' context (Anakwenze \& Zuberi, 2013; Bassett \& Moore, 2013; Berg et al., 2010; Bissonnette et al., 2012; Dunn, 2002; Eagle, 2015; Mitchell \& Popham, 2008; Perkins \& Speer, 2009; Rogers et al., 2008; Roundtree,2011; Williams- Goldhagen, 2017). In short, they are both the environment and the experience.

External conditions can be social, structural, and systemic or a mix of each; yet all continuously perform, create and perpetuate particular psycho-social, emotional and cognitive effects which can weaken or strengthen individual and collective agency and wellbeing within the community environment (Anakwenze \& Zuberi, 2013; Bassett \& Moore, 2013; Berg et al., 2010; Bissonnette et al., 2012; Brown et al., 2005; Dunn, 2002; Eagle, 2015; Mitchell \& Popham, 2008; Kondrat, 2013; Rogers et al., 2008; Wandersman \& Nation,1998; Webb \& Webber, 2016; Williams-Goldhagen, 2017). These can include socio-economic circumstances, access and quality of housing, the presence of agencies and businesses within the community, the existence and influence of various social groups, stakeholders, political actors and policies, new developments, positioning and/or expansion of existing or new services within the community, level of incivilities as well as opportunities, supports and spaces for building and strengthening social cohesion and greater wellbeing (Eagle, 2015; Ellaway et al., 2014; Kondrat, 2013; Lopez, 2009; Williams- Goldhagen, 2017).

In the excerpts below, Gavin and Jackson share stories of their experiences with the external socialities (Clandinin and Connelly, 2000) of the Sherbourne and Dundas environment. 
The testimonies offer the readers the opportunity to critically reflect on how this day to day experience with entrenched aspects of this particular environment which have informed and influenced their individual and collective contexts.

Gavin expresses his living experiences of coming into the Sherbourne and Dundas neighbourhood straight from a boys home and speaks to what he saw as the influence of external socialities (Clandinin and Connelly, 2000) within the Sherbourne and Dundas neighbourhood and later as an adult being an active community member engaging with representations of power within his community space and shares how it has and continues to impact his journey of recovery, survivorship, as a single parent and in his advocacy work with and within this community.

Gavin: You know today's child being orphaned and without family- you know. Through group homes, the trainings schools, foster homes, orphaned; being on the street. And they just kicked me to the street you know, the director of St. John's put me in a car sent me right here and brought me onto Yonge (street). He drove me all the way around, 'this is where', you know, 'Track One where they sell themselves. This is Track Two, where the trannies are. This is Track Three, where they sell themselves... the gay guys, the women over there, so that you'll be okay. Oh and I'll take you over to College and Yonge... right there, there's the Y (YMCA), over there, and there's the place to stay. But there's the gym. There's the gym, there's where you go shop, you know. He knew everything, the director. He knew all the people on the street and fucking everything! The guy from Oxbridge, the Director of St John's, knew downtown fucking Toronto like the back of his fucking hand. You tell me how?!! Unless he's procuring prostitution. Yeah! He's procuring these young 
guys for the next years and decades. And they want to turn them gay, or bi, or weird, you know, and put them on the street and (they fucked them up already), so then they will be doing, because they're used to doing that shit. The more vulnerable, the more extreme shit you see, they don't even care. I know how these guys end up, missing- LOTS, like fifty of my foster brothers you know have died, been murdered, been killed. (name) OD'd died in jail, or die by tricks, been strangulated, shot, stabbed, whatever.... injection, you know, all kinds of crazy. Another two, three hundred people I've known personally.

Gavin speaks to just some of the experiences of violence that he has experienced through and over time since entering this neighbourhood. Gavin's specialized knowledge was borne directly out of personal experiences with torment and victimhood as a youth which was only prolonged unjustifiably by the reproductions and recreations of violence and unchecked power through a series of actors and structures over decades. Alice, Gavin and Jackson all speak to the ability of the power brokers within the Sherbourne and Dundas community to move freely and make serious decisions with little to no redress nor accountability for the situations and spaces which they help to create and ultimately maintain. These community spaces are then managed through a series of social controls which work to gate keep voices of complaint and dissent. These institutional behaviours and practices help to maintain the power of these agents and structures to continue their practice of mining the community and occupying these neighbourhood spaces, painting themselves as helpers and positioning the vulnerable as incapable and needing to be 'managed'. Each of the participants voiced the need for greater, specialized supports to be placed in the community and made it clear that serious changes needed to be made in order to make the community safer and more stable for all. 
In the following section Jackson shares his experience of being released from a US prison, ending up back in Canada as an adult, briefly experiencing homelessness on Seaton Street and then being placed in social housing in the Sherbourne and Dundas community. Jackson then shares how this environment has contributed to the struggles he has had in coping with and healing from experiences with childhood trauma and long- term institutionalization that preceded him arriving here. He then speaks to the physical, psychological and emotional (re) traumatization and stigmatization of upon placement within the Sherbourne and Dundas community by actors, agencies and structures empowered within the space. Jackson shares knowledge and self-reflection concerning his own understanding of the external socialities of the space and what he has witnessed in how this environment has impacted himself and his fellow neighbours in terms of expressing agency, building capacity and other aspect related to safety, belonging, health and wellbeing. Finally, Jackson speaks to the ongoing and amplifying incivilities, related constant states of trauma and fear of crime of living and moving through Sherbourne and Dundas and the baseline of trauma that he and others have had to cope with as part of having to navigate in well over a decade of intensifying violence, sights and smells of suffering and constant states of trauma that he and many other residents who live in and around Sherbourne and Dundas are living in crisis.

Jackson: "So I live in social housing community complex here. Sure. At Sherbourne and Dundas, which is Toronto Community Housing. As to how I arrived there. I was incarcerated in the United States for 16 years as a youthful offender and I was released into Toronto with no support, no monetary capabilities and was homeless for a period of time and went through Seaton house, Streets to Homes, Seaton House. And I had found housing 
out in Scarborough, but it was rather precarious. And my housing worker from Seaton house, because I had been through Seaton House and was on their, their data sheet I was then qualified to go to Dan Harrison. Little did I know that this community building is in was and has been, what it is, or what it was, or what it's always been or what it could be or what it shouldn't be. Um...And that's how I wound up there. Actually, in all seriousness, my worker from Seaton house, he expressed to me that the previous tenant who'd been there who'd come through Seaton House. He didn't identify the individual, had been there had been in a good position as far as sobriety, and was doing really well, and within ten days of being in the unit, he then had close to 15 people living in a bachelor unit. And my neighbor, who was living there at the time, expressed how the police were there. Almost, he said 99 times within 100 days. So that immediate transition into police attention and generally serious calls to people being attacked, fights within the unit, fires being started. Sometimes sexual acts being performed on miners who are being sex trafficked, either by drug dealers, or whatever John's happened to be coming into the building to utilize the services of the miners. So there's a lot of activity going on. And my worker from Seaton House stated to me that my experience in prison would help me deal with my housing placement and Toronto Community Housing specifically at this community complex.

Interviewer: And do you take the walks?

Jackson:Yeah, not just the quiet, but it's like I want to get away from the sense of people. Because it's just you can only take so much misery. And it's like, even in prison. Obviously, people are going to be miserable people are going to be angry. There's, there's the whole gambit of emotions in there. And then there are times when because of whatever the situation is that emotions are running high. The thing is, is that in prison, 
your ability to self-regulate in relation to others, is there's a path. You have a 40 -year sentence; you have a 15 years sentence, so you know that that's the direction that you're working on, that that's my goal. And there no, well I don't want to say it's lack of clarity, in the context of Dan Harrison, but on an institutional-level, because there's no there's no, there's no reset, you know. That there's a little bit of polish on the turd, that's about it! But it's still a turd and it doesn't change it. And that's... it's inherently depressing that this is where people that....So Dan Harrison, Dan Harrison's history being, the first place that was non-for- profit, social housing in Toronto. And it was originally intended for poor families, obviously, but families and single women. And because of the change in...I want to say institutionalized mind-set, but I don't think that's really what it was. The courts kind of Courts, the Government forced the issue as to how people with mental health issues were treated in this country, on the presumption that they had agency. So they didn't turn these people out of institutions, dumped them on the streets, and the City played catch up, and they use their housing portfolio to take on that burden. And there's documentation that shows that at least in 1991, Dan Harrison had a population of about 10\% of deinstitutionalized persons. And by ....by the time I got there, I would say that figure was probably closer to $60 \%$, as far as the bachelor units, if not 70 . And a lot of those people, some of them were convicted as ex -felons, however, you want to phrase that, but a lot, a lot of them are people that came from supportive housing situations, or severe, that had severe mental impediments, violent, episodic violence. That does not even... you're not even contextualizing within that, the drug trade, which in turn, a lot of these people have been experimented and tested on. 
Gavin, Jackson, and Alice all made strong connections between the external socialities (Clandinin and Connelly, 2000) intermeshed within their community environment and spoke to the changes they had to make as a result of the health and safety of the environment influencing their ability to act with agency and ultimately enact to navigate within their neighbourhood. Gavin's, Jackson's and Alice's experiences of violence have become depoliticized and normalized. In living here for decades Alice has borne witness to and experienced an incredible amount of suffering and brutality while Gavin and Jackson over the past decade have daily witnessed and directly experienced this violence and misery as a crescendo to their childhood and adult traumas. It is through the living experience of this environment that they have all largely received the message from those with power in the neighborhood and writ large the City that this is their lot of being in this position, of being a resident in this environment. The violence and power structures get reinforced and reproduced daily which constantly informs her of the status quo: to know that they, their family and their neighbours will keep experiencing the violence and just have to try to avoid it, hide from it and then be quiet about it. Their testimonies recounted many experiences which reaffirmed the theories held in community and enviro psychology that see the environment both built, systemic and social as inseparable from influencing, shaping and informing identity and wellbeing, which could hold profound implications for enacting agency and self-determination (Eagle, 2015; Hughey, Mitchell \& Popham, 2008; Kondrat, 2013; Rogers et al., 2008; Wandersman \& Nation,1998; Webb \& Webber, 2016; Williams-Goldhagen, 2017)..

Inclusively contained throughout all three NIs were persistent and noteworthy themes present in the sharing of participants experiences including: changes in the interviewees' ability to navigate within their neighbourhood environment, experiences that impacted them inside 
their home and outside within their community environment, experiences of engaging with local service agencies and power structures embedded in the community, personal experiences of violence and bearing witness to acts and/or outcomes of violence within the community environment. All participants also described shifts in their own behavior while living in, and/or as a result of the community environment at Sherbourne and Dundas. Remarkably each of the participants also expressed a conscious growth in self (determined) awareness to choose better ways of being in relationship with their neighbours and other community members, all participants also expressed stories of practicing advocacy for themselves and also on behalf of their neighbours. Finally, all participants expressed visions for the future and offered direction towards strengthening community safety and capacity. 


\section{CHAPTER 5: DISCUSSION \& IMPLICATIONS - NEW BEGINNINGS}

This inquiry served to contribute to better understanding the impact of the social, structural and built environment on the safety, health, and wellbeing of those who live at Sherbourne and Dundas. This inquiry also took a holistic look at the neighbourhood environment through the lens of spatial justice via interviewees' representations; which are farmed by this researcher as specialized environmental knowledge held by people with lived experience (PWLE) in order to unmap the Sherbourne and Dundas environment, including the social, structural, physical and systemic aspects which work to perform, reproduce, influence and maintain space.

My thesis correctly asserted that environment, identity, health and wellbeing are inextricably linked (Anakwenze \& Zuberi, 2013; Aubry et al., 2011; Bassett \& Moore, 2013; Berg et al., 2010; Bissonnette et al., 2012; Dunn, 2002; Eagle, 2015; Hughey, Mitchell \& Popham, 2008; Kondrat, 2013; Lewin, 1936; Rogers et al., 2008; Wandersman \& Nation,1998; Webb \& Webber, 2016; Williams-Goldhagen, 2017). The participants' testimonies through the NI affirmed how each was experiencing, influencing and being influenced by the neighbourhood environment. The interviewees' representations within this research helped to recentre people with lived experience' voices and show how people who live in their neighbourhoods have specialized environmental knowledge about how the social, structural and systemic make-up of the environment is impacting neighbourhood safety, agency, social cohesion and wellbeing (Bailey et al., 2016; Eagle, 2015; Ellaway et al., 2014; Kondrat, 2013; Lewin, 1936; Rogers et al., 2008; Williams-Goldhagen, 2017). Those who live within the Sherbourne and Dundas neighbourhood are the ones carrying the stories, pain, trauma and memory of all those socialstructural and environmental impacts. 
As I noted in my literature review there has been a dearth of data specific to this community, yet currently the numbers, NI testimonies and reports show (Brillinger, 2018; Doolittle, 2009; Hande, 2018; Home, n.d.; Toronto Community Housing, 2018) that the level of threats to safety, incivility and stability are increasing and greatly affecting the residents who participated in this research and all those around them. The interviewees' representations of the power structures within their neighbourhood contain very rich expressions and insights, helping to contextualize appearance vs. reality with regards to the force-multiplying impacts that the social, structural and systemic environment at Sherbourne and Dundas has on those who live and try to recover there, including the most vulnerable (Bassett \& Moore, 2013; Berado et al., 2018; Capra, 1996; Dunn, 2002; Eagle, 2015; Ellaway et al., 2014). This position and research reaffirm social psychologist Kurt Lewin's (1936) equation $\mathrm{B}=\mathrm{f}(\mathrm{P}, \mathrm{E})$ Behavior (B) is $a$ function (f) of the Person (P) in their Environment (E) which are further supported through research and dialogues in community psychology (Bassett \& Moore, 2013; Bond et al., 2012; Eagle, 2015) and enviropsychology (Brown et al., 2005; Kondrat, 2013; Mitchell \& Popham, 2008) about causation and persistent connections between identity, cognition, health, social cohesion and ultimately the ability to act with agency and live with dignity in these spaces (Aubry et al., 2011; Bassett \& Moore, 2013, Corsínjiménez, 2003; Eagle, 2015; Ellaway et al., 2014).

The NI held themes which spoke to a shared story of the multi-trajectory impacts of the personal and collective stigma and the entrenched social, structural and systemic constructs distributed amongst power brokers through various representations within the neighbourhood space. The community members interviewed spoke to the many ways in which the power brokers preformed, established, and maintained power as well as influence in their community while 'managing' the crisis in their neighbourhood. According to the testimonies gathered this 
was not done in order to mitigate and reduce risk to the community members but by policing discourse and gatekeeping dissent. In its presentation, this hybrid of violence in its many representations within the community used silencing, stigma and exclusion to maintain power. In effect, this is to stifle, sway, disrupt, even thwart individual and collective will and determination to be self-organized, peer-supported, community centered, and socially adaptable. This also disrupts any calls which encourage and demand structures and systems to support and be accountable to the community's vulnerable population which would support health, recovery and sobriety.

Common themes were also identified through the NI process which showed that these living stories, these memories, which bond people, to place, environment and the collective experience, including how they perceive themselves are part of an extension of self-identity (Bassett \& Moore, 2013; Capra, 1996; Eagle, 2015; Williams-Goldhagen, 2017). The residents who participated showed through their own stories and self-reflections that they are more than just residents of this neighbourhood; instead, they are physically, socially, emotionally and cognitively connected to this space and are really extensions of the land expressing itself. They were consistent in showing that they found it difficult to differentiate themselves from the social, structural and physical composition of the environment and carried those experiences with them in ways that are difficult to measure: mentally, emotionally and physically; and show without a doubt that their connection to the neighbourhood environment is intimately reciprocal (Bassett \& Moore, 2013; Capra, 1996; Shepard, 1982; Williams-Goldhagen, 2017). These theories support the view that although there is duplicity within the justifications for the patterns and disorder which marks particular urban settings (Bassett \& Moore, 2013; Bond et. al, 2012; Eagle, 2015; Hande, 2018), there continues to be empirical evidence (Bassett \& Moore, 2013; Bond et. al, 
2012; Mitchell \& Popham, 2008), which affirms that there are non-dualistic connections between the memory of the environment and the weight it carries, and impacts it has in relation to their living- experiences, their access to quality of life and ability to actualize agency and be selfdetermining in their neighbourhood environment (Bassett \& Moore, 2013; Eagle, 2015; Lafrance \& McKenzie-Mohr, 2017).

This agrees with the understanding that we as citizens, neighbors and social workers and the environment, are all being influenced and influencing the bodies of communities surrounding both within and without (Eagle, 2015; Lewin, 1936; Williams- Goldhagen, 2017). This starkly affirms my thesis point: that the environment and people are non-dualistic and their relationships are reciprocal (Lewin, 1936; Williams- Goldhagen, 2017). There needs to be a holistic appreciation of the neighbourhood environment when agencies are occupying space, that they should only practice of their agencies, programs, staff and operations to improve the quality of life and social cohesion of a neighbourhood space; if not, how could they be doing so for the most vulnerable? This perspective needs to be central to moving forward in being communitycentred and empowered when developing, running and evaluating programs, agencies, and structural presence.

Through the community members' lenses, I shared how this drives and impacts not only their future but our very own. The interview process of reclaiming their neighborhood through their living-narratives was intimate, passionate and generous; very much reflective of the people who live here. The stories and insights coherently express the residents interviewed long journey filled with undue suffering, heightened awareness of the social and physical environment associated with constant states of trauma, fear of crime and the impacts of integrating within the social matrix of highly diverse, vulnerable and complex people. The reciprocal relationships with 
this environment are very much part of their identities and through the community members own testimonies show that they are intimately intermeshed throughout their continuous acts of resistance and resurgence as they are fluidly embodied in the very cognition of their minds, bodies, and environment (Lewin, 1936; Williams-Goldhagen, 2017).

The community members interviewed persistently voiced their resistance to the violence, occupation of their spaces and pleaded for support and intervention, through the structures and systems within social housing, to resident tables, and all the way to the many ward councillors' office for well over a decade (Bailão \& Wong-Tam, 2019). This is further corroborated by the testimonies provided by the interviewees who all spoke to the mismanagement of this neighbourhood space as well as the entrenched systemic structural and social abuses of power. With power left unchecked we see the erosion and demise of the people, the environment and the neighbourhood because there is no separation (Eagle, 2015; Shepard, 1982; WilliamsGoldhagen, 2017). It is this much-unchecked power across the structures within the Sherbourne and Dundas community which has kept this neighbourhood occupied by outsider representations, the funded, exalted and empowered power brokers within this community space. This community has been mired in structures and programming which chiefly do not reflect best practices, nor have a vision with measures to show progress in building and enhancing the community's capacity. This stigmatized community needs to get their neighbourhood back so that they can be free from all the structures and paid actors who have a track record of reproducing the violence, dependence, isolation, and unhealthy social and physical spaces that deinstitutionalization was originally sought out to free the vulnerable from.

We should encourage and support our community, which includes service users, neighbours, stakeholders, staff, first responders and the like to come forward when they 
recognise that things are failing, or falling apart and never be silenced or thwarted by gatekeepers regardless of what form they take or what angle they come from; because ultimately it is their community and their life that is being impacted and if it's not safe and stable for the residents who live in and around Sherbourne and Dundas it can't be any better for those who are deeply entrenched in poverty, those who are pregnant or with young children, the disabled, the elderly and/or those who have addictions and mental health struggles and the many others who live here and are vulnerable (Bailão \& Wong-Tam, 2019, Toronto Community Housing, 2018; Hande, 2018). It is time for communities to be given back their neighborhoods. Everything within the community environment should enable greater health and be enhancing a holistic and reciprocal dynamic so that health and safety and dignity extend to all.

The outcome of this initial research shows that there is a clear and evident need for improved methods for community members and people who use services in the community to be more involved in the types of services being offered to their community. There also needs to be a clearer more accessible method for people to file complaints, provide feedback and to whistle blow when necessary. There is also a strong desire for those who create the policies, structures and actors responsible for designing, activating and animating these programs and services to centre the voices of the community, including the vulnerable as experts. As I have found throughout the course of my research within the Sherbourne and Dundas community that anything less weaponizes poverty, reproduces stigma, essentializes the power-over aspects foundational within abusive, silencing, isolating relationships while simultaneously implicitly informing those who have been abused, traumatized and/or institutionalized that the bars or be it the hand that hurts have merely become less visible and harder to challenge. 
The research objective for this NI at Sherbourne and Dundas was intentional in setting about to work with community members in reclaiming places for their community, in a historically subjugated space. In having met with and performed the inquiries I have recognized that this research also serves as a document, outlining the beginning of a community impact statement which reveals just a small portion of the hybridization of institutionalization, entrenched and empowered within this community environment. Employing NI as a methodology in this community has presented the interviewees, the researcher and all those who engage with this knowledge sharing with a critical opportunity for learning through and past discomfort, and a place with which to explore our own relationships and connections with community environments. It is highly important to consider given the density of this city's population and its growing vulnerability (Bailão \& Wong-Tam, 2019; Brillinger, 2018; Hande, 2018; Toronto Community Housing, 2018) that we be very clear, cognizant and accountable to how we define and defend our communities in terms of health, safety and stability so that we all have quality of life and sustainable spatial justice. If we are clear on our definitions, shared values and shared meaning, then we can readily and courageously stand together to defend them, as they will be challenged. This will also help us to align how we address quality of life, quality of care and the relational aspects of the person in the environment and the reciprocal dynamic that takes place, especially in neighborhoods dense with social disorder, suffering and illness.

Finally, the study also provides direction for social workers and researchers regarding the benefits of doing more targeted research. In doing so the community, researchers and institutions which serve them will have a shared source of accurate data to use in order to respond to the many serious mounting issues relating to health, safety and place. Sound research needs to be done not for the purposes of pathologizing or problematizing this community, but needs to take 
place in order as part of an initial response to concerns which community members have repeatedly identified as impacting their ability to connect, interact and express agency with the people and environment around them.

This research process has pushed me to step out of my own comfort zone and take hold of the responsibility to deliver this vital knowledge to the academic realm as well as to the greater public realm as it greatly expands our understanding of the neighborhood environment especially for the growing population of stigmatized and vulnerable. The testimonies and current conversations in the City and across the community have corroborated the conditions and realities of this environment (Bailão \& Wong-Tam, 2019; Brillinger, 2018; Hande, 2018; Toronto Community Housing, 2018). Therefore, all systems, actors and structures need to be held accountable, because currently it is the community who is paying the costs and the debt is increasingly visible, palpable and unbearable. 


\section{APPENDICES}

\section{Appendix A: Recruitment Flyer}

\section{REB file number (2018-484)}

To whom it may concern,

My name is Stephanie Beausoleil, and I am a Masters of Social Work student at Ryerson University's School of Social Work. I am currently completing a major research project on the impacts that the neighborhood environment have on the people who live there; and am seeking people from the Sherbourne and Dundas community to share their stories. Specifically I am looking for people to share their lived experiences including concerns, challenges, acts of resistance; as well as visions for the future. I am looking to gather stories from the people who live here rather than the way that people from outside tell the story of this community. I am hoping that you would be interested in participating in this study yourself and also please pass this invitation onto anyone else you know who lives in this community who may like to share their story for this study.

I am looking for three adults between the ages of 19 to 99 who have been living in the community of Sherbourne and Dundas for more than one year. They must live within the boundaries of Gerrard to Shuter and George Street to Ontario Street. Otherwise there are no other restrictions to participating.

The purpose of this research study is to hear from the people who live in the Sherbourne and Dundas neighborhood and their experiences of living in this environment. The interview can take up to 1.5 hours to complete. I will be asking you about your first impressions of living in the neighborhood. I will then ask what you identify as the community's strengths. I am then going to 
ask if you have any concerns they have about the neighborhood's safety and wellbeing. I will then be asking if you have any stories/ experiences that you would like to share about times you worked by yourself and/or with other neighbors/community members to make their neighborhood safer, more welcoming etcetera. In concluding the interview I will ask what you think is the most important to you to have in this community and then how you would like to see this community change in the years to come.

Participation in the research study is voluntary and there will be no penalties should you decline this offer or choose to withdraw from the study. I really appreciate you taking the time to read this invitation and please do pass it on to others living within the neighborhood.

If you are interested in the study or obtaining more information about the study, please feel free to contract me at the email address provided below.

Thank you in advance for your time and consideration.

Sincerely,

Stephanie Beausoleil, BSW

School of Social Work at Ryerson University

sbeausoleil@ryerson.ca 


\section{Appendix B: Oral Consent Agreement}

\section{Stephanie Beausoleil \\ Ryerson University: Oral Consent Agreement}

REB file number (2018-484)

[Where separate written participant information has already been read by the participant beforehand, and oral consent is then sought.]

I will be recording this consent process using a digital recorder (if participant has consented to this).

You are being invited to participate in a research study. Please read this consent form so that you understand what your participation will involve. Before you consent to participate, please ask any questions to be sure you understand what your participation will involve.

Project Title: MANAGING CRISIS AND LIVING IN CRISIS: Health \& Place, What

Separation? A Holistic View of the Community Environment at Sherbourne and Dundas

\section{INVESTIGATORS:}

This research study is being conducted by Stephanie Beausoleil, the principal investigator of the study. This research is being conducted under the supervision of Dr. Samantha Wehbi in order to fulfill the requirements of my Master's degree.

Stephanie Beausoleil BSW

School of Social Work at Ryerson University sbeausoleil@,ryerson.ca

Samantha Wehbi, MSW, PhD, MFA

School of Social Work, Faculty of Social Work at Ryerson University 4169795000 ext. 6221 swehbi@,ryerson.ca

If you have any questions or concerns about the research, please feel free to contact me at the email provided.

Purpose of the Study: This study is going to look at the ways in which the community environment of those living and /or working in and around Sherbourne and Dundas impacts residents' sense of safety and wellbeing. Specifically, it will be seeking 3 participants who live in the area to provide their stories of living and engaging within the community and ultimately how they might envision a community that promotes health and wellbeing. 
What Participation Means: Your participation in this study will consist of an in-person interview. The interview should take approximately 1.5 hours to complete. If you agree to participate, I will be asking you questions about your story and experience of living in the Sherbourne and Dundas Community.

- I will ask you to tell me your story, in whatever way you feel best represents you (you will not be required to give me any confidential information at any time during the interview).

- I will also ask you to tell me about an experience you had in your community when you asked for help

- I will also ask you to tell me about concerns you have about your safety and wellbeing in the community.

- I will ask you how you would like to see your community in the future

- Our interview should be approximately 1.5 hours, but you will be able to decide how long you are comfortable talking for. The interview will take place at a mutually agreed upon location which ensures both auditory and visual privacy.

- This interview will be digitally recorded, but you have the right to ask me to stop the recorder at any time. You may also review the transcripts of the interview for accuracy by contacting me at the number and/or email provided below. The digital audio recording will be erased immediately after the interview has been transcribed.

Risks or Discomforts: During this interview, you may experience some discomfort due to the nature of the questions or physical discomforts due to the length of the interview. Interviews will be held strictly on a voluntary basis and I would like to assure you that we can completely stop the interview at any point or take a break, whichever you prefer. If you should choose to withdraw from the study the data collected will be immediately discarded. Please let me know of this option by May 1, 2019. Ultimately, it is your story I want to hear and you may decline to answer anything at any time. I will provide you with a list of resources for community supports for you to access should you need them.

Confidentiality: This interview will be kept strictly confidential and all identifying information will be omitted from the transcripts and audio recordings. Excerpts of this interview may be made part of research reports, presentations or articles, but under no circumstances will your name or any identifying characteristics be included in any way. Audio recordings will be password protected. Once the recordings have been transcribed, they will be destroyed. Your name and phone number will also be deleted once this interview has completed. Transcripts will not have your name or identifying information on them; pseudonyms will be assigned to participants in order to ensure confidentiality. All of the necessary steps will be taken to ensure your confidentiality is maintained throughout the research process to minimize risks.

Costs and/or Compensation for Participation: I am available to meet at the location of our mutual agreement, such as (1) a private room at the Ryerson University Library which can guarantee aural and visual privacy, or (2) within the Sherbourne Dundas community at a private place of your choosing. As a researcher, I will ensure that all locations chosen will have both visual and auditory privacy to ensure your confidentiality.

- Voluntary Nature of Participation: Participation in this study is voluntary. Your choice of whether or not to participate will not influence your future relations with me, or with Ryerson 
University. If you decide to participate, you are free to withdraw your consent and to stop your participation at any time without any consequence to you. You have until May $1^{\text {st }}, 2019$ to withdraw your consent and your interview will be destroyed/ erased. At any particular point in the study, you may refuse to answer any particular question or stop participation altogether. If you decide to stop I will ask you how you would like us to handle the data collected up to that point. This could include destroying it or using the data collected up to that point. Ultimately it is up to you. The final date to withdraw consent is May $01^{\text {st }}, 2019$.

Questions about the Study: If you have any questions about the research now, please ask. If you have questions later about the research, you may contact:

Stephanie Beausoleil, BSW

School of Social Work, Ryerson University

sbeausoleil@ryerson.ca

Samantha Wehbi, MSW, PhD

School of Social Work, Faculty of Social Work at Ryerson University

4169795000 ext. 6221

swehbi@ryerson.ca

If you have questions regarding your rights as a human subject and participant in this study, you may contact the Ryerson University Research Ethics Board for information. This study has been reviewed by the Ryerson University Research Ethics Board. If you have questions regarding your rights as a participant in this study please contact:

Research Ethics Board

c/o Office of the Vice President, Research and Innovation

Ryerson University

350 Victoria Street

Toronto, ON M5B 2K3

416-979-5042

rebchair@ryerson.ca

Project Title: MANAGING CRISIS AND LIVING IN CRISIS: Health \& Place, What Separation? A Holistic View of the Community Environment at Sherbourne and Dundas

\section{Agreement:}

Your oral consent indicates that you have read the information in this agreement and have had a chance to ask any questions you have about the study. Your oral consent also indicates that you agree to be in the study and have been told that you can change your mind and withdraw your consent to participate at any time up until May $01^{\text {st }}, 2019$. You have been given a copy of this agreement. You have been told that by providing oral consent agreement you are not giving up any of your legal rights. 
Name of Participant (Please Print)

Signature of Participant Date

I agree to be audio recorded for the purposes of this study. I understand how these recordings will be stored and destroyed.

Signature of Participant

Date

Signature of Investigator

Date 


\section{Appendix C: Interview Guide}

REB file number (2018-484)

\section{Introduction}

(After reading, explaining and signing the consent form) Thank you for agreeing to participate in this interview. I would like to make sure that you are clear that if at any time you would like to stop the interview we can and if you need me to stop for a break and/or stop recording the interview I can. This interview will not be very formal, and it may take approximately 1.5 hours to complete. I do have a few questions for you but you are free to answer as few or as many of them as you are comfortable with. Ultimately, it is your story and insight I want to hear and you may decline to answer anything at any time. Further, I would like to mention that since the nature of the topic being discussed is quite personal, there is not an expectation that you have an answer to every question, or that you are willing to provide details of every experience.

\section{Background}

Before I ask you to tell me about your story of living in the Sherbourne and Dundas community, is there anything you would like me to know about you?

\section{Story}

I would like to hear about your story of coming into this neighborhood and your experiences in it since then. You can tell this story in whatever way you feel best represents you and you are free to leave out anything you don't wish to share.

\section{Possible guiding questions:}

- I will ask you to tell me your story, in whatever way you feel best represents you (you will not be required to give me any confidential information at any time during the interview).

- What was your first impression of living in the area?

- Could you please tell me about any concerns you have about your safety and wellbeing in the community.

- Could you please tell me about any experience(s) you had while living here that made you feel upset or worried?

- Could you please tell me about an experience you had in your community when you asked for help? 


\section{Retelling and Reclaiming Space}

I would like to know if you have any stories/experiences in which you through your own action and/or with other community members worked to make your own space/ building/ community safer and/or 'better'

\section{Possible guiding questions:}

- Has the way you interact with your community changed over the years?

- What was the most positive experience you have had living in this community?

- Is there anything that is helping you to manage with living in this community?

- What is most important to you as a member of this community?

- What do you see as steps that need to be taken to make this community safer and healthier?

- How would you like to see this neighborhood in the years to come?

\section{Concluding remarks}

I would like to extend my sincerest thanks to you for taking the time to talk to me and to share your story with me. If there anything else you would like to add that we may not have discussed yet, feel free to let me know? Do you have any concerns regarding our interview?

I am happy to share the findings of the interview with you once I have finished the study and have left my contact information with you for this reason, as I will be deleting your name and number to protect your privacy once the interview is complete. Please know you have until May $01^{\text {st }}, 2019$ to withdraw your consent. Furthermore, I would welcome your feedback upon completion of my research. Thank you again for your time and for sharing your experiences and knowledge with me. 


\title{
Appendix D: Resources for Participants
}

\section{The Gatehouse}

To provide support, community, and resources for individuals impacted by childhood sexual abuse.

Provide a range of both formal and informal support and outreach.

http://thegatehouse.org/

Address: 3101 Lake Shore Blvd West, Toronto, ON M8V 3W8

Phone: (416) 255-5900

\section{Canadian Centre for Men and Families (CCMF)}

Provides a broad range of mental health, legal, parenting, and abuse support programs geared at boys, men, fathers and their families.

201-2 Homewood Ave.

Toronto, ON, M4Y 2J9 Map

647-479-9611

1-844-900-2263 (Toll Free)

www.menandfamilies.org/

\author{
Anishinawbe Health Toronto \\ Primary Health Care Services \\ Diabetic Education and Prevention \\ Traditional Family Service \\ Aboriginal Mental Health and Addiction Services \\ Address: 179 Gerrard, St E, Toronto, ON \\ Phone: 416-920-2605 \\ Fax: 416-920-8876
}

Traumatic Loss Survivor Support Program - Distress Centres

https://www.aht.ca/Toronto Downtown Central Toronto ON Canada

VisitWebsite:info@torontodistresscentre.com

416-595-1716 General Info

416-408-4357 Crisis Line

\section{Toronto Rape Crisis Centre / Multicultural Women Against Rape}

Crisis line -- Mon-Sun 24 hours

office -- Mon-Fri 9:30 am-5 pm

counselling by appointment

Services

Crisis intervention and culturally sensitive counselling, support and referral * support for families and friends of survivors * support groups * information on alternatives to legal justice system * court support, accompaniment and advocacy program * research, public education, workshops * comprehensive volunteer training * all services confidential * transpositive environment 


\section{Appendix E: Ethics Clearance Certificate}

\section{Research Ryerson Ethics Board}

To: Stephanie Beausoleil

Social Work

Re: REB 2018-484: Managing Crisis and Living in Crisis: Health \& Place, What Separation? A Holistic View of the Community Environment at Sherbourne and Dundas

Date: February 19, 2019

Dear Stephanie Beausoleil,

The review of your protocol REB File REB 2018-484 is now complete. The project has been approved for a one year period. Please note that before proceeding with your project, compliance with other required University approvals/certifications, institutional requirements, or governmental authorizations may be required.

This approval may be extended after one year upon request. Please be advised that if the project is not renewed, approval will expire and no more research involving humans may take place. If this is a funded project, access to research funds may also be affected.

Please note that REB approval policies require that you adhere strictly to the protocol as last reviewed by the REB and that any modifications must be approved by the Board before they can be implemented. Adverse or unexpected events must be reported to the REB as soon as possible with an indication from the Principal Investigator as to how, in the view of the Principal Investigator, these events affect the continuation of the protocol.

Finally, if research subjects are in the care of a health facility, at a school, or other institution or community organization, it is the responsibility of the Principal Investigator to ensure that the ethical guidelines and approvals of those facilities or institutions are obtained and filed with the REB prior to the initiation of any research.

Please quote your REB file number (REB 2018-484) on future correspondence.

Congratulations and best of luck in conducting your research.

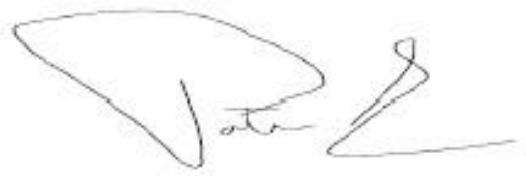

Dr. Patrizia Albanese, $\mathrm{PhD}$

Chair, Ryerson University Research Ethics Board 


\section{REFERENCES}

Anakwenze, U., \& Zuberi, D. (2013). Mental health and poverty in the inner city. Health \& Social Work, 38(3), 147-157. doi:10.1093/hsw/hlt013

Aubry, T., Chambers, C., Farrell, S., Hubley, A. M., Hwang, S. W., Palepu, A., Nisenbaum, R., (2011, August 20). The health and housing in transition study: A longitudinal study of the health of homeless and vulnerably housed adults in three Canadian cities. Retrieved November 14, 2018, from https://link.springer.com/article/10.1007/s00038-011-0283-3

Bailão, A. \& Wong-Tam, K. (2019). The Dan Harrison community complex master plan. Motion prepared for the City Council at Toronto City Hall. Toronto, ON.

Bailey, A., Guruge, S., Hyman, I., Patel, S., Vahabi, M., Wilson-Mitchell, K., \& Wong, J. P. (2016). Taking action on violence through research, policy, and practice. Global Health Research and Policy, 1(1). doi:10.1186/s41256-016-0006-7

Bassett, E., \& Moore, S. (2013). Social capital and depressive symptoms: The association of psychosocial and network dimensions of social capital with depressive symptoms in Montreal, Canada. Social Science \& Medicine, 86, 96-102. doi:10.1016/j.socscimed .2013 .03 .005

Berado, D., Diamonti, A., Gutowski, E., Liang, B. \& White, A. (2018). How stress influences purpose development: The importance of social support. Journal of Adolescent Research, 33(5), 571-597. Retrieved September 28, 2018, from

http://journals.sagepub.com/doi/abs/10.1177/0743558417737754 
Berg, A. E., Groenewegen, P. P., Maas, J. \& Verheij, R. A. (2010). Green space as a buffer between stressful life events and health. Social Science \& Medicine, 70(8), 1203-1210. doi:10.1016/j.socscimed.2010.01.002

Bissonnette, L., Bell, S., Shah, T. I. \&Wilson, K. (2012). Neighbourhoods and potential access to health care: The role of spatial and aspatial factors. Health \& Place, 18(4), 841-853. doi:10.1016/j.healthplace.2012.03.007

Bond, L. (2004, November 02). Community Psychology. Retrieved January 22, 2019, from https://compact.org/resource-posts/community-psychology/

Bond, L., Egan, M., Kearns, A., Mason, P., Tshehill, C., \& Whitely, E. (2012). Exploring the relationships between housing, neighbourhoods and mental wellbeing for Interviewees of deprived areas. BMC Public Health, 12(48). Retrieved October 02, 2018.

Bozikovic, A., McHugh, P.\& Pahwa, V. (2017). Toronto architecture: A city guide. Toronto, Ont.: McCelland \& Stewart.

Brillinger, C. (2018). Closing the service gap in the downtown east revitalization area. Report prepared for the Community Development and Recreation Committee. Toronto, ON: Social Development, Finance and Administration, City of Toronto.

Brown, P., Leger, L., Maller, C., Pryor, A. \&Townsend, M. (2005). Healthy nature healthy people: 'contact with nature' as an upstream health promotion intervention for populations. Health Promotion International, 21(1). Retrieved September 22, 2018, from https://www.ncbi.nlm.nih.gov/pubmed/16373379.

Capra, F. (1996). The web of life. New York: Anchor Books 
Clandinin, D. J. (2013). Developing qualitative inquiry. Engaging in narrative inquiry. Walnut Creek, CA, US: Left Coast Press.

Clandinin, D. J., \& Connelly, F. M. (2000). Narrative inquiry: experience and story in qualitative research. San Francisco: Jossey-Bass Publishers.

Corbiere, A., McGregor, D.; Migwans, C. (2013) Anishinaabewin NISWI: Deep roots, new growth 2012. M’Chigeeng, Ontario: Marquis Book Printing Inc.

Corsínjiménez, A. (2003). On Space as a Capacity. Royal Anthropological Institute, 9(1), 137153. doi:10.1111/1467-9655.t01-1-00008

Creswell, J.W. (2013). Five qualitative approaches to inquiry. In Qualitative inquiry and research design (3rd ed.). Los Angeles: SAGE.

Dalton, J., Hill, J., Kloos, B., Thomas, E., \& Wandersman, A. (2015). Community psychology: Linking individuals and communities (3rd ed.). Retrieved January 24, 2019, from https://www.google.com/url?sa=t\&rct=j\&q=\&esrc=s\&source=web\&cd=2\&cad=rja \&uact= 8\&ved=2ahUKEwiP0uPsi5nkAhWC1FkKHemrCdkQFjABegQICBAC\&url=http://theeye.eu/public/Books/BioMed/Community Psychology - Linking Individuals and Communities 3rd ed. - B. Kloos, et. al., (Cengage, 2012) WW.pdf\&usg=AOvVaw3_pTB4E10vj9DYGabJspxt

Doolittle, R. (2009, September 01). Dundas-Sherbourne ranks No. 1 in violence. Retrieved January 11, 2019, from https://www.thestar.com/news/gta/2009/09/01/dundassherbourne_ranks_no_1_in_violence. html

Dunn, J. (2002). Housing and inequalities in health: A study of socioeconomic dimensions of housing and self reported health from a survey of Vancouver Interviewees. Journal of 
Epidemiol Community Health, 56(67), 671-681. Retrieved September 22, 2018, from https://www.ncbi.nlm.nih.gov/pmc/articles/PMC1732232/.

Eagle, G. (2015). Crime, fear and continuous traumatic stress in South Africa: What place social cohesion? Psychology in Society, (49), 83-98. doi:10.17159/2309-8708/2015/n49a7

Ellaway, A., Jones, R., Heim, D. \& Hunter, S., (2014). The relative influence of neighbourhood incivilities, cognitive social capital, club membership and individual characteristics on positive mental health. Health \& Place, 28, 187-193. Retrieved September 24, 2018, from https://www.ncbi.nlm.nih.gov/pubmed/24911971.

Evans, S., Gately, C. Huxley, P. \& Rogers, A. (2008). More than jobs and houses: Mental health, quality of life and the perceptions of locality in an area undergoing urban regeneration. Soc Psychiatry Psychiatr Epidemiol, 43, 364-372. Retrieved September 27, 2018, from https://www.ncbi.nlm.nih.gov/pubmed/18274693

Flowers, S. E. (2016). Icelandic magic: The mystery and power of the Galdrabók grimoire. Rochester: Inner Traditions.

Gee, K.; Spencer, C. (2009, February). The roots and branches of environmental psychology. Retrieved November 23, 2018, from https://thepsychologist.bps.org.uk/volume-22/edition2/roots-and-branches-environmental-psychology

Government of Canada, Interagency Advisory Panel on Research Ethics. (2017, October 12). Interagency Advisory Panel on Research Ethics. Retrieved November 02, 2018, from http://www.pre.ethics.gc.ca/eng/policy-politique/initiatives/tcps2-eptc2/Default/

Hande, M. J. (2018). Disability consciousness on the frontlines of urban struggle. Antipode, 5l(2), 558-578. doi:10.1111/anti.12499 
Harrell, S. (2018). "Being human together": Positive relationships in the context of diversity, culture, and collective well-being. In M. A. Warren \& S. I. Donaldson (Eds.), Toward a positive psychology of relationships: New directions in theory and research (pp. 247-284). Santa Barbara, CA: Preager.

Home. (n.d.). Retrieved February 11, 2019, from https://www.metrac.org/what-wedo/safety/?doing_wp_cron=1564170170.7909529209136962890625

Hughey, J., Perkins, D. D. \& Speer, P. W. (2009). Community psychology perspectives on social capital theory and community development practice. Journal of the Community Development Society, 33(1), 33-52. doi:10.1080/15575330209490141

Isaacs, W. (1993). Dialogue: The power of collective thinking. The Systems Thinker, 4(3). Retrieved May 24, 2019, from https://thesystemsthinker.com/wpcontent/uploads/pdfs/040301p.pdf.

Kondrat, M. E. (2013, June). Person-in-Environment. Retrieved October 24, 2018, from http://oxfordindex.oup.com/viewindexcard/10.1093\$002facrefore\$002f9780199975839.01 3.285

Kovach, M. (2009). Indigenous methodologies: Characteristics, conversations and contexts. Toronto: University of Toronto Press.

Lafrance, M., \& Mckenzie-Mohr, S. (2017). Narrative resistance in social work research and practice: Counter-storying in the pursuit of social justice. Qualitative Social Work: Research and Practice, 16(2), 189-205. doi:10.1177/1473325016657866

Levy, S. (2019, August 04). LEVY: Dundas-Sherbourne neighbourhood "under siege". Retrieved August 05, 2019, from https://torontosun.com/news/local-news/levy-dundas-sherbourneneighbourhood-under-siege 
Lewin, K., Heider, F., \& Heider, G. M. (1936). Principles of topological psychology. New York: McGraw-Hill Book.

Lopez, R. P. (2009). Public health, the APHA, and urban renewal. American Journal of Public Health, 99(9), 1603-1611. doi:10.2105/ajph.2008.150136

Metropolitan Action Committee on Violence Against Women and Children. (2010). Safety Audit Report Card [PDF file]. Retrieved from www.metrac.org/wp-content/uploads/2014/06/sherbourne.dundas.10.pdf

Metropolitan Action Committee on Violence Against Women and Children. (2014). Safety Audit Report Card [PDF file]. Retrieved from www.metrac.org/wp-content/uploads/2014/06/sherbourne.dundas.10.pdf

Mitchell, R., \& Popham, F. (2008). Effect of exposure to natural environment on health inequalities: An observational population study. Lancet, 372, 1655-1660. Retrieved October 03, 2018, from https://www.thelancet.com/journals/lancet/article/PIIS01406736(08)61689-X/fulltext.

Moffitt, K. (n.d.). Structural-functional theory in sociology: Definition \& examples. Retrieved December 21, 2018, from https://study.com/academy/lesson/structural-functional-theoryin-sociology-definition-examples-quiz.html

Nation, M. \& Wandersman, A., (1998). Urban neighborhoods and mental health: Psychological contributions to understanding toxicity, resilience, and interventions. American Psychologist, 53(6), 647-656. Retrieved October 02, 2018, from https://www.ncbi.nlm.nih.gov/pubmed/9633265. 
P. (2012, March 05). First say to yourself what you would be; and then do what you have to do. Retrieved November 21, 2018, from https://philosiblog.com/2012/03/05/first-say-toyourself-what-you-would-be-and-then-do-what-you-have-to-do/

Parenteau, D. \& Saldanha, K. (2013). "“Well, if you can't smile you should go home!” Experiences and reflective insights on providing outreach to young sex trade workers," Children and Youth Services Review, Elsevier, vol. 35(8), pages 1276-1283.

Roesdahl, E. (2016). The Vikings. London: Penguin Books.

Roundtree, J. (2011). Joining inner and outer approaches to freedom: Meeting the needs of developing communities. Journal of Humanistic Psychology, 51(3), 291-273. Retrieved October 08,2018 , from https://www.researchgate.net/publication/238044082 Joining Inner and Outer Approach es_to_Freedom_Meeting_the_Needs_of_Developing_Communities

Saccone, J. (2011, August 24). St. Michael's Hospital. Retrieved November 23, 2018, from http://www.stmichaelshospital.com/media/detail.php?source=hospital_news/2011/2011082 $\underline{4 \mathrm{a} h n}$

Shephard, P. (1982). Nature and madness. Athens, Georgia: The University of Georgia Press. Smith, K. (2011). Occupied spaces: Unmapping standardized assessments in health and Social justice social work (2 ${ }^{\text {nd }}$ ed. pp., 197-208). Black Point: Fernwood. social service organizations. In D. Baines (Ed.) Doing anti-oppressive practice

Toronto Community Housing (2018). Community safety-broader dan harrsion community pilot: Item 5 [PDF file]. Retrieved from https://www.torontohousing.ca/events/Documents/TSC/July\%2020\%202018/Item\%205\%2 $\underline{0-}$ 
\%20final.pdf.

Toronto Police Services. (n.d.). TPS Crime App (Year-to-Date). Retrieved January 22, 2019, from

http://torontops.maps .arcgis.com/apps/webappviewer/index.html?id=5f74f910b2ea4e85a3 70014921cdecbd

Williams-Goldhagen, S. (2017). Welcome to your world: How the built environment shapes our lives. New York, NY: Harper, an imprint of HarperCollins.

Webb, B., \& Webber, S. (2016). The implications of condominium neighbourhoods for longterm urban revitalisation. Cities, 61, 48-57. doi:10.1016/j.cities.2016.11.006

Wong-Tam, K. (2017). Closing the service gap in the downtown east revitalization area. Motion prepared for the City Council at Toronto City Hall. Toronto, ON. 